\title{
Apoptosis and Autophagy: Decoding Calcium Signals that Mediate Life or Death
}

\author{
Michael W. Harr ${ }^{1,4}$ and Clark W. Distelhorst ${ }^{1,2,3}$ \\ ${ }^{1}$ Division of Hematology and Oncology, Department of Medicine, Case Western Reserve University, Cleveland, \\ Ohio 44106 \\ ${ }^{2}$ Department of Pharmacology, Case Western Reserve University, Cleveland, Ohio 44106 \\ ${ }^{3}$ Case Comprehensive Cancer Center, Case Western Reserve University, Cleveland, Ohio 44106 \\ ${ }^{4}$ Molecular Pharmacology and Chemistry Program, Sloan-Kettering Institute, Memorial Sloan-Kettering \\ Cancer Center, New York, New York 10021 \\ Correspondence: cwd@case.edu
}

Calcium is a versatile and dynamic 2 nd messenger that is essential for the survival of all higher organisms. In cells that undergo activation or excitation, calcium is released from the endoplasmic/sarcoplasmic reticulum to activate calcium-dependent kinases and phosphatases, thereby regulating numerous cellular processes; for example, apoptosis and autophagy. In the case of apoptosis, endogenous ligands or pharmacological agents induce prolonged cytosolic calcium elevation, which in turn leads to cell death. In contrast, there is now evidence that calcium regulates autophagy by several mechanisms, and these may be important for maintaining cell survival. Here we summarize what is known about how calcium regulates these life and death decisions. We pay particular attention to pathways that have been described in lymphocytes and cardiomyocytes, as these systems provide optimal models for understanding calcium signaling in the context of normal cell physiology.

\begin{abstract}
A poptosis is a process of programmed cell death or suicide that occurs when cells have undergone irreversible stress or damage. It is required to maintain normal cell homeostasis or to eliminate a population of cells that may be harmful to the organism or unnecessary during organ development (Green 2003). For example, it is the primary mechanism by which potentially autoreactive $\mathrm{T}$ cells are eliminated from the immune system. There are two conventional apoptosis pathways: the extrinsic pathway, which is typically initiated by death receptors (e.g., Fas) on the plasma membrane
\end{abstract}

and the intrinsic (mitochondrial) pathway, which involves permeabilization of the outer mitochondrial membrane followed by the release of cytochrome c. In this review, we primarily focus our attention on the intrinsic pathway due to the importance of intracellular calcium in the regulation of this process.

In brief, cytochrome $c$ release stimulates apoptosis via its interaction with the protein Apaf-1, which in turn activates the initiator caspase- 9 and the executioner caspase-3 (Green 2005). Caspases comprise a family of cysteine proteases that are essential for the classically

Editors: Martin D. Bootman, Michael J. Berridge, James W. Putney, and H. Llewelyn Roderick Additional Perspectives on Calcium Signaling available at www.cshperspectives.org

Copyright (C) 2010 Cold Spring Harbor Laboratory Press; all rights reserved; doi: 10.1101/cshperspect.a005579

Cite this article as Cold Spring Harb Perspect Biol 2010;2:a005579 
M.W. Harr and C.W. Distelhorst

observed cellular and biochemical characteristics of apoptosis, which include (but are not limited to) membrane blebbing, chromatin condensation, and DNA fragmentation. Another class of cysteine proteases, calpains, require calcium for their activation and are important mediators of apoptosis following ER stress. As discussed later in this review, calpains are reported to directly activate caspases, thus promoting apoptotic cell death independent of mitochondrial cytochrome $\mathrm{c}$ release. The following sections provide a more detailed explanation of the varied ways in which calcium signals induce cell death and are themselves regulated.

\section{APOPTOSIS REGULATION BY ANTIGEN RECEPTORS: A MODEL FOR PROGRAMMED CELL DEATH}

Much that is known about calcium signaling came from immunological studies using activated lymphocytes (Berridge 1997). Immature $\mathrm{T}$ cells are an ideal model for investigating apoptosis because they are programmed to die during development. This is evident by the fact that $95 \%$ of double positive (i.e., CD4/ CD8) thymocytes undergo apoptosis as a consequence of negative selection (Starr et al. 2003). Apoptosis of thymocytes occurs when self antigen presented on thymic epithelial cells binds to T-cell receptors with strong avidity (Hogquist 2001). As depicted in Figure 1, ligation of the T-cell receptor activates a signaling pathway that results in autophosphorylation of Src family kinases Lck and Fyn, which are recruited to the plasma membrane to phosphorylate the zeta chain of the T-cell receptor (Latour and Veillette 2001; Mustelin and Tasken 2003; Palacios and Weiss 2004). Activation of these kinases facilitates the hydrolysis of phosphatidylinositol 4,5-bisphosphate by phospholipase $\mathrm{C} \gamma$, thereby generating diacylglycerol and inositol 1,4,5-trisphosphate $\left(\mathrm{IP}_{3}\right)$ (Lewis 2001). $\mathrm{IP}_{3}$ mediates ER calcium release through the opening of $\mathrm{IP}_{3}$ receptors $\left(\mathrm{IP}_{3} \mathrm{Rs}\right)$, which in turn stimulates calcineurin-mediated activation of the nuclear factor for the activation of $\mathrm{T}$ cells (NFAT) (Gallo et al. 2006; Winslow and Crabtree 2005; Winslow et al. 2003). Cytosolic calcium release is also mediated by ryanodine receptors, which are calcium channels expressed in lymphocytes, cardiomyocytes, and neurons. It has been suggested that ryanodine receptors facilitate calcium flux in response to nicotinic acid adenine dinucleotide phosphate (NAADP) and cyclic adenosine dinucleotide phosphate ribose, both of which are produced during T-cell activation (Berg et al. 2000; Dammermann et al. 2009; Guse et al. 1999). However, unlike ADP ribose, the notion that NAADP is a direct activator of ryanodine receptors is not yet certain and may be context- or cell-type specific (Galione and Petersen 2005). Nevertheless, the generation of these 2nd messengers, along with $\mathrm{IP}_{3}$, may be required for robust calcium elevation in response to antigen receptor stimulation.

In general, lymphocyte activation encodes distinct patterns of calcium signaling, which ultimately regulate cell proliferation, survival, and apoptosis (Berridge 1997; Lewis 2001) (Fig. 1). It has been proposed that strong agonist stimulation of T-cell receptors generates calcium transients that trigger apoptosis, whereas weak stimulation produces calcium oscillations that are needed for cell survival (Randriamampita and Trautmann 2003). The patterns of calcium elevation following strong and weak agonist stimulation are vastly different. For example, calcium transients can be detected in cells 1-2 minutes following activation of the T-cell receptor. They are generally synchronized and characterized by a broad peak that is high in amplitude. On the other hand, calcium oscillations consist of asynchronous and repetitious spikes that persist for as long as one hour following activation. Using fluorescence-activated cell sorting, we have shown that $\mathrm{T}$ cells with a high level of cytosolic calcium more readily undergo apoptosis compared to those that have lower levels (Zhong et al. 2006). Further, in those cells that undergo calcium oscillations in response to weak agonist stimulation, NFAT is rapidly de-phosphorylated, and this is associated with increased levels of IL-2 mRNA (Harr et al. 2009; Zhong et al. 2006). These observations are consistent with the strength of signal theory, which states that $\mathrm{T}$ cells undergo positive or negative selection 


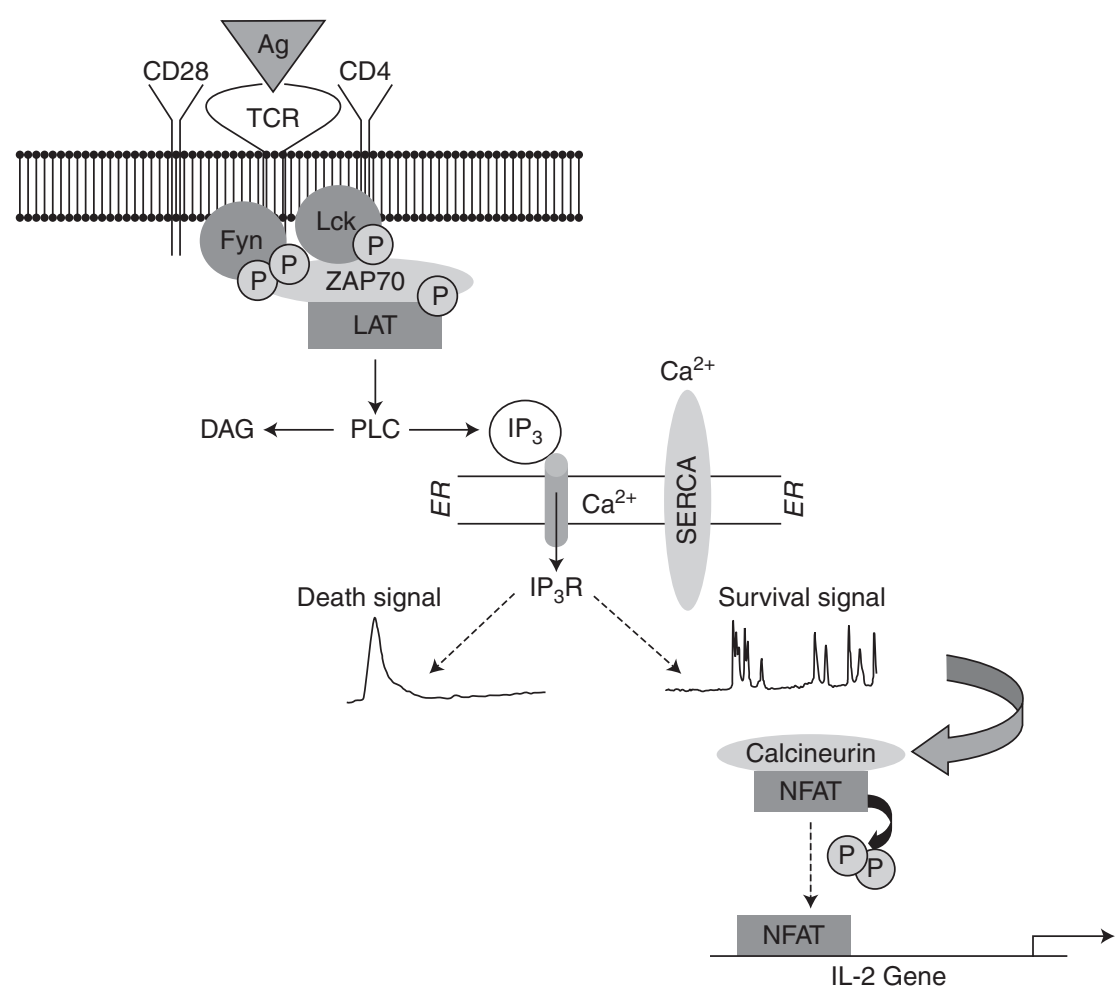

Figure 1. Calcium signaling mediated by T-cell activation. In a CD4 positive T cell, activation is induced by antigen binding to the T-cell receptor (TCR) and a co-stimulatory signal mediated by ligation of CD28. Src family kinases Fyn and Lck are activated by autophosphorylation and recruited to the plasma membrane to associate with CD3 (TCR) and CD4, respectively. This in turn leads to the phosphorylation of ZAP-70 and the adaptor protein LAT in order to activate phospholipase $\mathrm{C}$ and generate 2 nd messengers $\mathrm{IP}_{3}$ and diacylglycerol (DAG). $\mathrm{IP}_{3}$ binds to the $\mathrm{IP}_{3} \mathrm{R}$, resulting in ER calcium release. Calcium is released into the cytosol by way of a single calcium transient (left), which is associated with cell death by apoptosis. On the other hand, calcium oscillations activate calcineurin, which dephosphorylates NFAT, thereby sending it to the nucleus to activate transcription of IL-2. The Sarcoplasmic/Endoplasmic Reticulum Calcium ATPase (SERCA) is responsible for maintaining the appropriate concentration of luminal calcium by actively transporting calcium across the ER membrane.

according to the avidity of T-cell receptor activation(Hogquist 2001; Mariathasanetal. 1998). This provides one example in which the amplitude and frequency of calcium signals encodes information that regulates apoptosis or cell survival.

\section{APOPTOSIS REGULATION BY HORMONES AND OTHER SIGNALING MOLECULES}

\section{Corticosteroids}

Knowledge of calcium-dependent apoptosis evolved from studies examining the effects of glucocorticoids on immature T cells. Glucocorticoids, such as cortisol, are physiological immunomodulatory hormones that regulate immune cell development. Pharmacologically, synthetic glucocorticoids, such as prednisone and dexamethasone, are widely used to treat autoimmune disease and cancer (e.g., leukemia and lymphoma) because of their ability to suppress the immune system and selectively kill immature lymphocytes, respectively. Glucocorticoid hormones are secreted from thymic epithelial cells to antagonize self-antigen recognition in immature thymocytes (Ashwell et al. 2000). Thus, glucocorticoids negatively regulate $\mathrm{T}$-cell activation by attenuating $\mathrm{T}$-cell receptor signaling (Baus et al. 1996; Lowenberg et al. 2005; Van Laethem 
et al. 2001). Conversely, T-cell receptor signaling can also inhibit glucocorticoid-induced apoptosis, a concept known as mutual antagonism (Ashwell et al. 2000; Jamieson and Yamamoto 2000; Tolosa and Ashwell 1999).

While studying these inhibitory effects on T-cell activation, our laboratory discovered that short-term treatment with glucocorticoids modulates T-cell receptor-mediated calcium elevation by converting calcium transients to oscillatory signals (Harr et al. 2009). However, prolonged glucocorticoid treatment with pharmacological concentrations of prednisone or dexamethasone results in thymocyte apoptosis by a mechanism that is dependent, in part, on de novo transcription (Herold et al. 2006). Importantly, glucocorticoid-induced apoptosis in thymocytes is consistently associated with a sustained rise in cytosolic calcium (Bian et al. 1997; Cohen and Duke 1984; Kaiser and Edelman 1977; Lam et al. 1993; McConkey et al. 1989; Orrenius et al. 1991). This increase in cytosolic calcium is associated with the classically observed biochemical characteristics of apoptosis, including DNA fragmentation and endonuclease activity. While there is evidence that cytosolic calcium elevation contributes to the induction of apoptosis, this mechanism has not been firmly established. Marks and colleagues found that anti-sense mediated knockdown of $\mathrm{IP}_{3} \mathrm{R} 1$ protected cells from apoptosis induced by dexamethasone (Jayaraman and Marks 1997). However, we observed that dexamethasone-mediated up-regulation of $\mathrm{IP}_{3} \mathrm{Rs}$ did not contribute to cytosolic calcium elevation or apoptosis following glucocorticoid treatment (Davis et al. 2008). An alternative theory is that dexamethasone down-regulates the sarcoplasmic endoplasmic reticulum ATPase (SERCA) that pumps calcium into the ER (Chai et al. 2009), thereby decreasing ER luminal calcium and inducing apoptosis.

\section{Angiotensins}

Angiotensins are a second class of hormone that induce calcium-dependent apoptosis, specifically Angiotensin II (Cigola et al. 1997; Kajstura et al. 1997; Palomeque et al. 2009; Yamada et al.
1996). Angiotensins are oligomeric peptides released in response to steroid hormones, such as glucocorticoids and estrogen. They are powerful vasoconstrictors, and consequently, angiotensin receptors are targets for antihypertensive medications (Gradman 2009). In a cardiomyocyte, muscle contraction is stimulated by the opening of an L-type calcium channel that enables calcium release via ryanodine receptors (Fig. 2). Angiotensins bind to their receptors (AT1 and AT2) resulting in the generation of $\mathrm{IP}_{3}$ followed by transient calcium elevations (Mattiazzi 1997). While ryanodine receptors are more abundant than $\mathrm{IP}_{3} \mathrm{Rs}$ in cardiomyocytes, both calcium and $\mathrm{IP}_{3}$ are required for $\mathrm{IP}_{3} \mathrm{R}$ channel opening. While still not universally accepted, it is likely that calcium release via neighboring ryanodine receptors facilitates $\mathrm{IP}_{3} \mathrm{R}$-opening, enabling both channels to function cooperatively in response to angiotensin ligands (Kockskamper et al. 2008).

Much like glucocorticoids, treatment with higher concentrations of angiotensin II results in apoptosis that can be blocked by receptor antagonists (Andreka et al. 2004). As depicted in Figure 2, stimulation of cardiomyocytes with angiotensin II causes an acute release of cytosolic calcium, and several reports suggest that calcium elevation contributes to apoptosis (Kajstura et al. 1997). For instance, verapamil, an L-type calcium channel blocker, inhibits angiotensin-induced apoptosis (Goldenberg et al. 2001). Further, ectopic expression of angiotensin receptors (AT1 and AT2) results in apoptosis by a calcium-dependent mechanism (AranguizUrroz et al. 2009).

\section{Testosterone}

Testosterone is a steroid hormone that has rapid effects on cardiomyocytes. In one study, it was shown that testosterone increased cytoplasmic calcium concentrations in 1-7 minutes by an $\mathrm{IP}_{3} \mathrm{R}$-dependent fashion (Vicencio et al. 2006). A second study reported that testosterone signals activate the extracellular signal-regulated kinase (ERK), and this activation could be inhibited by 2 -aminoethyldiphenyl borate and the phospholipase C inhibitor U-73122, suggesting 


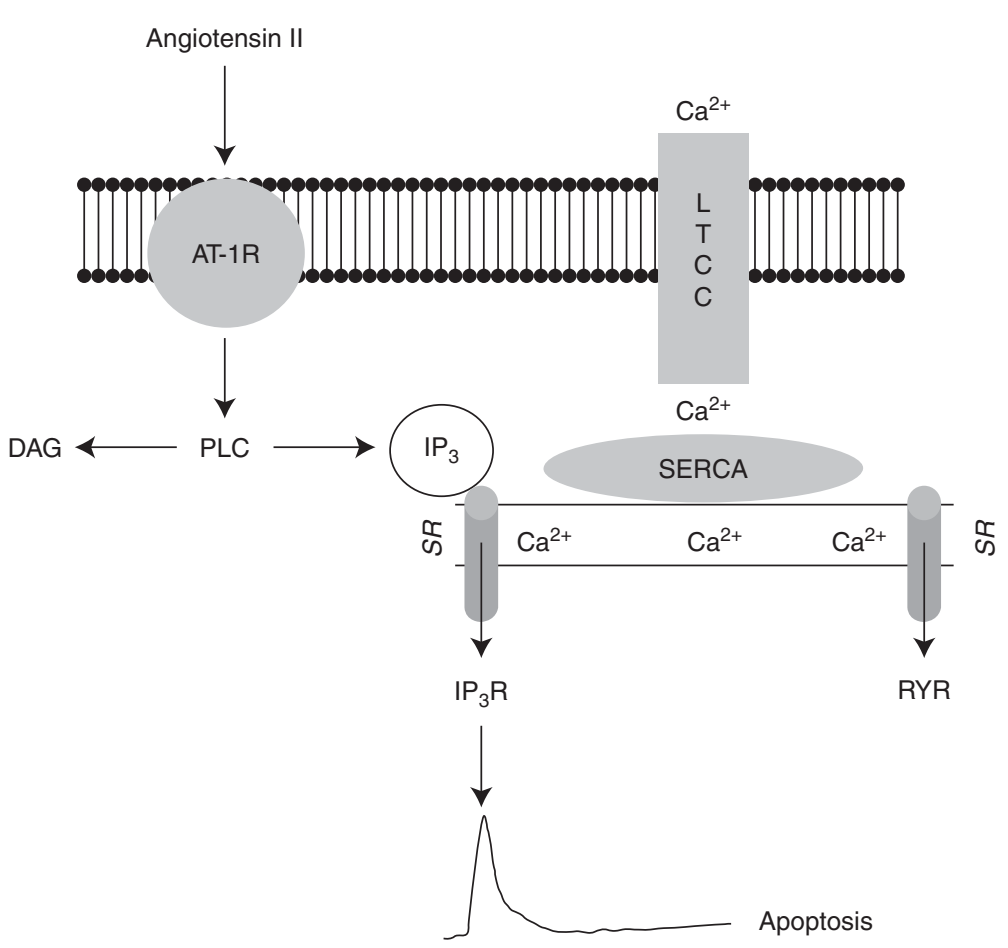

Figure 2. Calcium signaling mediated by angiotensin II hormone in a cardiomyocyte. In a cardiomyocyte, calcium signaling is mediated by the influx of calcium through L-type calcium channels (LTCC). The Sarcoplas$\mathrm{mic} /$ Endoplasmic Reticulum Calcium ATPase (SERCA) is responsible for maintaining the appropriate concentration of luminal calcium by actively transporting calcium ion across the SR membrane, while ryanodine receptors and $\mathrm{IP}_{3}$ Rs promote its release into the cytosol. Angiotensin, a peptide hormone, binds to the AT-1 receptor (AT-1R), a G-protein coupled receptor that activates phospholipase C (PLC) following GTP hydrolysis, thereby generating $\mathrm{IP}_{3}$ and diacylglycerol (DAG). It should be noted that ryanodine receptors are 50- to 100-fold more abundant than $\mathrm{IP}_{3} \mathrm{Rs}$ in cardiomyocytes. Therefore, calcium release via ryanodine receptors have shown to be much more robust compared to calcium responses that are mediated by $\mathrm{IP}_{3} \mathrm{Rs}$ (Kockskamper et al. 2008). Nevertheless, there is unequivocal evidence for the contribution of $\mathrm{IP}_{3} \mathrm{Rs}$ during SR-calcium release, which is likely due to synergy between the two calcium channels in mediating calcium-induced calcium release.

that testosterone generates $\mathrm{IP}_{3}$ in cardiomyocytes (Altamirano et al. 2009). Similar rapid non-genomic effects of testosterone have been observed in $\mathrm{T}$ cells, where calcium influx was observed within seconds (Benten et al. 1997). However, it remains to be determined whether these calcium signals would eventually lead to apoptosis. Interestingly, in neuronal cells, low concentrations of testosterone result in calcium oscillations, whereas higher concentrations induce apoptosis, also by a mechanism that is $\mathrm{IP}_{3} \mathrm{R}$ dependent (Estrada et al. 2006). Thus, steroid hormones can have direct apoptotic effects on multiple cells types, as is the case for glucocorticoids and androgens, and perhaps indirectly via glucocorticoid regulation of angiotensin.

\section{Nitric Oxide}

Nitric oxide is an endogenous signaling molecule that regulates muscle contraction, oxygen consumption, and mitochondrial metabolism in the heart (Massion et al. 2003). It is produced by a family of calcium-dependent enzymes called nitric oxide synthases (NOS). NOS enzymes have been found to localize to the sarcoplasmic reticulum and can inhibit L-type channel 
and ryanodine-receptor activity (Barouch et al. 2002; Sears et al. 2003; Xu et al. 1999). Further, there is evidence that NOS enzymes can inhibit calcium channel activity by S-nitrosylation of thiol residues (Davidson and Duchen 2006; Razavi et al. 2005), which in turn decreases mitochondrial calcium uptake, thereby preventing cytochrome $\mathrm{c}$ release and mitochondrial metabolism (Brooks et al. 2000; Dedkova and Blatter 2005; Khan and Hare 2003). In addition, nitric oxide can also attenuate apoptosis by nitrosylation of caspases on cysteine residues (Dimmeler et al. 1997). The ability of nitric oxide to prevent apoptosis in a calcium-dependent manner may be important for understanding certain pathophysiologies such as ischemia or reperfusion injury.

\section{APOPTOSIS REGULATION BY PHARMACOLOGICAL AGENTS}

Although calcium-mediated apoptosis can occur by physiological signals, there are multiple cytotoxic agents that function to disrupt calcium homeostasis leading to apoptotic cell death. Among these are thapsigargin, staurosporine, and cisplatin.

\section{Thapsigargin}

Thapsigargin decreases the ER calcium pool by inhibiting SERCA pumps, which results in ER stress and apoptosis (Lam et al. 1993). Apoptosis induced by thapsigargin occurs by a mechanism that is dependent on the activation of caspase-12, a mammalian protease that localizes to the ER and is important for mediating apoptosis in response to ER stress (Szegezdi et al. 2003). This is exemplified by experiments performed in mice in which caspase-12 had been deleted (Nakagawa et al. 2000). In vitro studies have demonstrated that a calpain activates caspase-12 leading to the subsequent activation of caspase-9 (Morishima et al. 2002; Nakagawa and Yuan 2000; Rao et al. 2002). These data suggest the possibility that apoptosis induced by thapsigargin can occur independently of cytochrome c release and is thus directly induced by calcium via calpain activation.

\section{Staurosporine}

Staurosporine is a natural apoptosis-inducing alkaloid originally isolated from Streptomyces staurosporeus. It directly provokes calcium leak from the ER by activating caspase- 3 mediated cleavage of $\mathrm{IP}_{3} \mathrm{R} 1$ (Hirota et al. 1999). Additionally, it was shown that cleavage of $\mathrm{IP}_{3} \mathrm{R} 1$ contributed, in part, to the induction of apoptosis by accelerating calcium leak (Assefa et al. 2004; Verbert et al. 2008). In these experiments, transfection of a mutant $\mathrm{IP}_{3} \mathrm{R}$ resistant to caspasemediated cleavage partially inhibited apoptosis induction by staurosporine in B cells lacking wild type $\mathrm{IP}_{3}$ Rs. A recent study by Mikoshiba and colleagues further identified $\mathrm{IP}_{3} \mathrm{Rs}$ as being important mediators of apoptosis induction by staurosporine. They determined that $\mathrm{G}$ proteincoupled receptor kinase interacting proteins (GITs) bind to $\mathrm{IP}_{3} \mathrm{Rs}$ to inhibit their function and suppress apoptosis in the presence of staurosporine (Zhang et al. 2009b). Finally, staurosporine also promotes the activation of a mitochondrial calpain that positively regulates apoptosis (Norberg et al. 2008), thus illustrating similarities with ER stress-driven pathways.

\section{Cisplatin}

A third example is cisplatin, a platinum-based chemotherapeutic agent used to treat several types of cancer. Cisplatin also causes an $\mathrm{IP}_{3-}$ $\mathrm{R}$-dependent increase in cytosolic calcium and subsequent activation of a calpain prior to the induction of apoptosis (Mandic et al. 2003; Schrodl et al. 2009; Splettstoesser et al. 2007). Further, cisplatin treatment results in ER stress as suggested by increased expression of Grp78 and activation of caspase-12 (Mandic et al. 2003). Interestingly, $\mathrm{IP}_{3} \mathrm{R} 1$ contributes to cisplatin sensitivity in bladder cancer, as knocking down its expression in cell lines mediates resistance to apoptosis (Tsunoda et al. 2005). These results collectively indicate that cisplatin induces apoptosis, in part, by disrupting calcium homeostasis in a variety of cell types. 


\section{APOPTOSIS REGULATION BY ANTI-APOPTOTIC BCl-2 FAMILY PROTEINS}

In each of the previous examples in which apoptosis is regulated by calcium, cell death can be readily inhibited by anti-apoptotic proteins such as B cell leukemia/lymphoma-2 (Bcl-2) and other Bcl-2 family members. As its name implies, Bcl-2 was first identified because it was overexpressed in B cell follicular lymphoma (Tsujimoto et al. 1985). Membership in the Bcl-2 family is defined by the presence of Bcl-2 homology domains (BH domains) (Chipuk et al. 2010). Bcl-2 has four BH domains. $\mathrm{BH} 1, \mathrm{BH} 2$, and $\mathrm{BH} 3$ are located within the $\mathrm{C}$ terminal half, where they participate in forming a hydrophobic groove that binds and thereby inhibits proapoptotic family members. The $\mathrm{BH} 4$ domain is located near the $\mathrm{N}$-terminus and connected to the C-terminal half of Bcl-2 by an unstructured loop, facilitating intra- and intermolecular interactions. It is now known that $\mathrm{Bcl}-2$ is overexpressed in a number of cancers because of its ability to inhibit cell death and promote survival of malignant cells (Cory and Adams 2002). In fact, Bcl-2 localizes not only to the outer mitochondrial membrane but also to the ER, where it regulates $\mathrm{IP}_{3}$-mediated calcium release. The observation that $\mathrm{Bcl}-2$ regulates calcium release from the ER was initially made more than 15 years ago (Baffy et al. 1993; Lam et al. 1994) and the overall importance of $\mathrm{Bcl}-2$ on the ER is exemplified in studies in which ER-targeted Bcl-2 inhibited apoptosis in response to agents that depolarize the mitochondrial membrane (Annis et al. 2001).

\section{The Bcl-2-IP 3 Receptor Interaction}

Our laboratory was the first to show that Bcl-2 directly interacts with $\mathrm{IP}_{3} \mathrm{Rs}$ to inhibit $\mathrm{IP}_{3}$ dependent calcium flux (Fig. 3) (Chen et al. 2004). This interaction, as well as an interaction of the $\mathrm{Bcl}-2$ homologue $\mathrm{Bcl}-\mathrm{xL}$ with the $\mathrm{IP}_{3} \mathrm{R}$, has subsequently been detected by a number of laboratories (Rong and Distelhorst 2007). Bcl-2 directly inhibits $\mathrm{IP}_{3} \mathrm{R}$ channel opening in vitro in lipid bilayer experiments and also inhibits $\mathrm{IP}_{3}$-induced calcium release in $\mathrm{T}$ cells (Chen et al. 2004; Zhong et al. 2006). We have

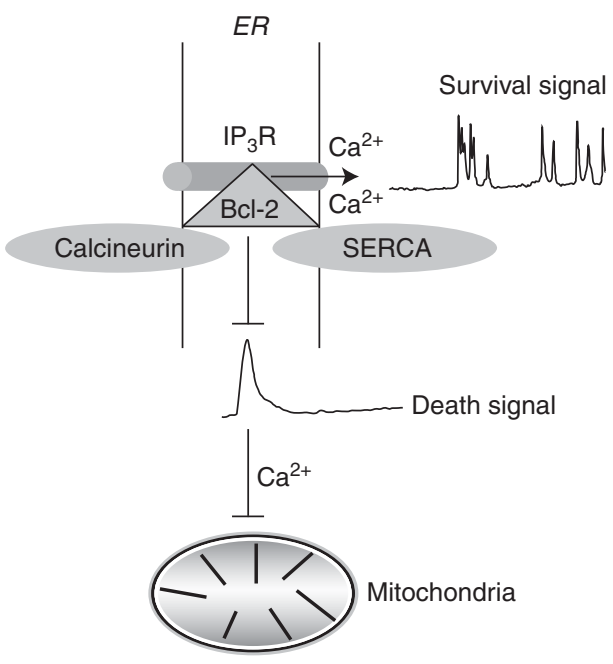

Figure 3. The Bcl-2-IP ${ }_{3} \mathrm{R}$ interaction inhibits ER-calcium release. Bcl-2 localizes to the ER where it binds $\mathrm{IP}_{3}$ Rs to inhibit calcium transients. In T cells, calcium transients are activated in response to strong T-cell receptor ligation, which results in apoptosis that can be inhibited by Bcl-2. In contrast, calcium oscillations that are associated with cell survival are promoted by $\mathrm{Bcl}-2$ and $\mathrm{Bcl}-\mathrm{xL}$. In addition, Bcl-2 regulates the level of ER luminal calcium by increasing membrane permeability or by interacting with the Sarcoplasmic/Endoplasmic Reticulum Calcium ATPase (SERCA). Bcl-2 also interacts with calcineurin, thereby forming a complex with both calcineurin and $\mathrm{IP}_{3}$ Rs on the ER membrane.

now further elucidated the mechanism of the $\mathrm{Bcl}-2-\mathrm{IP}_{3} \mathrm{R}$ interaction by demonstrating that the $\mathrm{BH} 4$ domain of $\mathrm{Bcl}-2$ associates with the regulatory and coupling domain of $\mathrm{IP}_{3} \mathrm{R} 1$, specifically an 80 amino acid sequence within domain 3 (Rong et al. 2008). Further analysis indicated that the $\mathrm{BH} 4$ domain was both necessary and sufficient to inhibit $\mathrm{IP}_{3}$-mediated calcium signals and subsequently apoptosis in T cells (Rong et al. 2009). This is particularly interesting given that the $\mathrm{BH} 4$ domain of $\mathrm{Bcl}$ 2 and $\mathrm{Bcl}-\mathrm{xL}$ seem to be involved in preventing apoptosis. Although our work has emphasized the interaction of $\mathrm{Bcl}-2$ with the regulatory and coupling domain of the $\mathrm{IP}_{3} \mathrm{R}$, there is also evidence that $\mathrm{Bcl}-2$ and/or $\mathrm{Bcl}-\mathrm{xL}$ may interact with the $\mathrm{C}$-terminus of the $\mathrm{IP}_{3} \mathrm{R}$, and through this interaction, enhance $\mathrm{IP}_{3}$-mediated calcium 
oscillations (White et al. 2005). In light of these discoveries, there is now increased interest in using small molecules to inhibit Bcl-2 and enhance proapoptotic calcium transients. One example of this was the use of a Bcl-2 inhibitor HA14-1 that induced cytochrome $\mathrm{c}$ release and apoptosis by a calcium-dependent mechanism in myeloid leukemia (An et al. 2004).

\section{Bcl-2 and IP ${ }_{3} \mathrm{R}$ Phosphorylation}

Other proteins within the $\mathrm{Bcl}-2-\mathrm{IP}_{3} \mathrm{R}$ complex may regulate ER calcium release by altering phosphorylation of $\mathrm{IP}_{3}$ Rs. As shown in Figure 3, $\mathrm{Bcl}-2$ binds the phosphatase calcineurin (Erin et al. 2003; Shibasaki et al. 1997), and calcineurin also interacts with $\mathrm{IP}_{3}$ Rs (Cameron et al. 1995). Because $\mathrm{IP}_{3} \mathrm{R}$ channel activity is positively regulated by phosphorylation (DeSouza et al. 2002), it is reasonable to speculate that Bcl-2 may facilitate the dephosphorylation of $\mathrm{IP}_{3} \mathrm{R}$ by interacting with calcineurin. Although such a mechanism has not been definitively established, we have observed that $\mathrm{IP}_{3} \mathrm{R}$ phosphorylation is decreased in Bcl-2 overexpressing T cells (Chen et al. 2004). Furthermore, $\mathrm{Bcl}-2$ has been reported to regulate $\mathrm{IP}_{3} \mathrm{R}$ phosphorylation in Bax/Bak double knockout cells (Oakes et al. 2005). Moreover, Xu et al. have implicated protein phosphatase 1 in the regulation of $\mathrm{IP}_{3} \mathrm{R}$ phosphorylation by Bcl-2 (Xu et al. 2007). Thus, much remains to be determined regarding the specific kinases and phosphatases that regulate $\mathrm{IP}_{3} \mathrm{R}$ channel opening, how these are regulated by $\mathrm{Bcl}-2-\mathrm{IP}_{3} \mathrm{R}$ interaction, and how they contribute overall to the regulation of calcium signals by $\mathrm{Bcl}-2$ and its relatives.

\section{Bcl-2 and Mitochondrial Cross Talk}

Another important function of Bcl-2 and Bcl$\mathrm{xL}$ is to inhibit calcium-mediated cross talk between ER and mitochondria (Kruman and Mattson 1999; Pinton et al. 2008). Because both organelles are in close proximity, calcium is rapidly taken up by mitochondria via the calcium uniporter on the outer mitochondrial membrane (Hajnoczky et al. 2006; Hanson et al. 2004; Rizzuto et al. 2003; Szalai et al.
1999; Szlufcik et al. 2006). Bcl-2 and Bcl-xL inhibit calcium redistribution to the mitochondria, thereby limiting calcium uptake (Hanson et al. 2008; Pinton et al. 2008) (Fig. 3). In the context of apoptosis, it was shown that Bcl-2 inhibited mitochondrial calcium uptake following IL-3 and serum withdrawal in hematopoietic cells and fibroblasts, respectively (Baffy et al. 1993; Magnelli et al. 1994). Interestingly, Bcl-2 inhibited apoptosis in cardiomyocytes exposed to ceramide and staurosporine, which caused depolarization of the mitochondrial membrane and cytochrome $c$ release (Pacher and Hajnoczky 2001). A more recent study suggests that Bcl-2 inhibits calcium release through L-type channels, thereby preventing mitochondrial calcium uptake (Diaz-Prieto et al. 2008). Finally, Mcl-1, an anti-apoptotic protein overexpressed in myeloid and lymphoid leukemia, also blocks calcium redistribution following exposure to staurosporine (Minagawa et al. 2005).

\section{Bcl-2 Regulation of Luminal Calcium}

In contrast to experiments reporting that Bcl-2 inhibits $\mathrm{IP}_{3} \mathrm{R}$ opening, there is also substantial evidence that $\mathrm{Bcl}-2$ and $\mathrm{Bcl}-\mathrm{xL}$ directly regulate the concentration of luminal calcium (Fig. 3). Initial studies showed that $\mathrm{Bcl}-2$ increased membrane permeability, thereby resulting in calcium leak and decreased signaling in response to ATP (Foyouzi-Youssefi et al. 2000; Pinton et al. 2000). Another study documented that knocking down Bcl-2 prevented the loss of ER luminal calcium (Oakes et al. 2005). While these studies also cite the significance of the $\mathrm{Bcl}-2-\mathrm{IP}_{3} \mathrm{R}$ interaction in regulating the calcium pool, others have found that Bcl-2 depletes luminal calcium by interacting with SERCA (Dremina et al. 2004; Dremina et al. 2006; Vanden Abeele et al. 2002). In spite of these differences in experimental findings, it cannot be refuted that Bcl-2 localizes to the ER to inhibit calcium signaling. Thus, mechanistic differences may be attributed to cell type in which the relative expression and localization of Bcl-2 family members are considerably distinct. Accordingly, the effect of luminal calcium is dependent upon the predominant $\mathrm{IP}_{3} \mathrm{R}$ isoform expressed, yet not 
necessary for Bcl-2 or Bcl-xL mediated effects on calcium signaling (Li et al. 2007).

\section{Bcl-2 Regulation of Prosurvival Calcium Signals}

Although Bcl-2 inhibits calcium transients that are associated with apoptosis, anti-apoptotic Bcl-2 family members can also enhance calcium oscillations that promote survival (Fig. 3). In $\mathrm{T}$ cells, Bcl-2 enhances calcium oscillations induced by weak $\mathrm{T}$ cell receptor stimulation and thus increases NFAT activation (Zhong et al. 2006). Similarly, Bcl-xL enhances prosurvival oscillations following weak ligand stimulation (Distelhorst and Zhong, unpubl). In DT40 B lymphocytes, Bcl-2, Bcl-xL, and Mcl-1 enhance calcium oscillations by sensitizing cells to lower concentrations of $\mathrm{IP}_{3}$ (Eckenrode et al. 2010; Li et al. 2007; White et al. 2005). This in turn leads to accelerated mitochondrial metabolism and cell survival. Additional studies in other cell types support this hypothesis by demonstrating that overexpression of $\mathrm{Bcl}-2$ enhances calcium oscillations in epithelial cells following stimulation with ATP and also in neuronal cells to facilitate survival (Jiao et al. 2005; Palmer et al. 2004).

\section{APOPTOSIS REGULATION BY PROAPOPTOTIC BCI-2 FAMILY PROTEINS}

In contrast to $\mathrm{Bcl}-2$, proapoptotic $\mathrm{Bcl}-2$ family proteins are missing a classic BH4 domain, although recent findings suggest the presence of consensus $\mathrm{BH} 4$ sequence in proapoptotic family members (Chipuk et al. 2010). Multidomain $\mathrm{BH}$ proteins (i.e., $\mathrm{BH} 1-3$ ) include $\mathrm{Bax}$ and Bak, both of which are essential for apoptosis driven by the mitochondrial pathway. Multiple studies using Bax/Bak knockout models have demonstrated that the loss of these proteins confers resistance to numerous apoptotic stimuli (Wei et al. 2001).

\section{Calcium Regulation by Bax and Bak}

Like Bcl-2 and Bcl-xL, Bax and Bak also localize to the ER where they regulate calcium homeostasis. In Bax/Bak knockout cells, ER luminal calcium is decreased compared to wild type cells, which compromises ER calcium release as well as mitochondrial uptake (Oakes et al. 2005; Scorrano et al. 2003). Consistent with these observations, the Bax Inhibitor-1 protein facilitates ER calcium leak, depleting the available calcium pool (Chae et al. 2004; Kim et al. 2008). Although the mechanism by which Bax and Bak decrease luminal calcium has not been determined, it is generally inferred that $\mathrm{Bax} / \mathrm{Bak}$ ordinarily prevents $\mathrm{Bcl}-2$-mediated ER calcium leak, and thus their deficiency promotes depletion of ER luminal calcium by $\mathrm{Bcl}-2$. Moreover, Bax alone is required for calcium elevation in response to cytotoxic agents, such as staurosporine (Nutt et al. 2002a). For example, reconstitution of Bax in a prostate cancer cell line augmented cytosolic calcium elevation and restored mitochondrial uptake. The same group also reported that Bax/Bak overexpression induced calcium elevation followed by cytochrome c release and apoptosis (Nutt et al. 2002b). Interestingly, when Bak is targeted to the ER, it facilitates cytosolic calcium elevation and activates caspase-12; yet this does not occur when Bak is specifically targeted to mitochondria (Zong et al. 2003). In addition, ER-targeted Bak requires calcium in conjunction with ER stress for apoptosis to occur (Klee et al. 2009). This suggests that the localization of Bax and/or Bak may determine which effector pathway is induced. It is possible that Bax/ Bak localization to the ER is favored when cells undergo apoptosis induced by ER stress.

\section{Calcium Regulation by BH3-only Proteins}

Other proapoptotic Bcl-2 family members have only the $\mathrm{BH} 3$ domain and therefore are designated as "BH3-only" proteins. These include Bim, Bad, Bik, BNIP3, PUMA, and NOXA (Cory and Adams 2002). Like their multidomain counterparts, these proteins also localize to both ER and mitochondria. At the mitochondria, BH3-only proteins facilitate Bax/Bak oligomerization by two potential mechanisms. In brief, one model suggests they function to directly activate Bax and Bak, whereas another suggests they do so indirectly by sequestering 
anti-apoptotic Bcl-2 family members (Cheng et al. 2001; Willis et al. 2007). Although the mechanism remains controversial, it is now certain that $\mathrm{BH} 3$-only proteins are necessary for $\mathrm{Bax} / \mathrm{Bak}$ activation and the induction of apoptosis.

While the role of these proteins at the mitochondria has been extensively studied, there are sufficient data to conclude that they also regulate apoptosis at the ER. For example, Bim translocates to the ER following ER stress and may be required for the activation of caspase-12 (Morishima et al. 2004). Thus, ER localization of Bim as well as Bak may be necessary for apoptosis in response to ER stress-inducing agents. Interestingly, dexamethasone induces Bim transcript and protein levels in T cells (Lu et al. 2006; Wang et al. 2003), a process that is associated with the elevation of cytosolic calcium and required for a robust apoptotic response. Engagement of T-cell receptors also stimulates de novo transcription of Bim by a calcium-dependent mechanism (Cante-Barrett et al. 2006). It has yet to be determined if this process contributes to apoptosis induced by T-cell receptor activation. Intriguingly, $\mathrm{T}$ cells deficient in Bim have impaired calcium release following their stimulation, and this is associated with increased binding of Bcl-2 to IP ${ }_{3}$ Rs (Ludwinski et al. 2009). Thus, another role of Bim may be to enhance calcium elevation by sequestering Bcl-2 away from $\mathrm{IP}_{3} \mathrm{Rs}$ at the ER membrane.

Bik is a $\mathrm{BH} 3$-only protein that promotes ER calcium depletion in a Bax/Bak dependent manner (Mathai et al. 2005). Similarly, BNIP3 causes a leak of ER luminal calcium when selectively targeted to the ER (Zhang et al. 2009a). NOXA and PUMA are both p53 target genes that are up-regulated in response to genotoxic stress. A study by Shore and colleagues has shown that NOXA may function cooperatively with Bik to promote the activation of Bax and Bak (Germain et al. 2005). A recent study indicates that the mitochondrial targeting region of NOXA functions to increase mitochondrial permeability and release calcium. Interestingly, a peptide corresponding to this region was able to induce calcium-dependent cell death by necrosis (Seo et al. 2009). This demonstrates that $\mathrm{BH} 3$-only proteins are not only important for regulating calcium flux and homeostasis, but may also function to regulate other mechanisms of cell death. Collectively, the Bcl-2 family makes up a network of proteins and each contributes to the regulation of normal calcium homeostasis. It is clear that alterations in expression or localization of these proteins can have profound effects on cell viability by inducing apoptosis.

\section{AUTOPHAGY}

Autophagy is a process of self-eating whereby cellular organelles and proteins are phagocytosed in order to produce energy during metabolic stress (Levine and Klionsky 2004). It is an evolutionarily conserved physiological process that is thought to promote cell survival. Some cellular contexts in which autophagy may be induced include nutrient deprivation, hypoxia, ER stress, abnormal cell growth, and microbial infection (Mizushima et al. 2008). On the other hand, autophagy has also been shown to promote cell death under certain conditions and stimuli. In fact, autophagy is often referred to as type II programmed cell death (distinct from type I programmed cell death) because it does not require caspase activation or DNA fragmentation, which are classical characteristics of apoptosis (Levine and Yuan 2005). However, it is likely that both processes occur simultaneously, and thus, it is important to understand the signaling pathways that govern autophagy, especially when considering that many of the same mechanisms regulate apoptosis.

During autophagy, double membrane vesicles, or autophagosomes, fuse with the lysosome, leading to the degradation of cellular proteins (Mizushima 2007). An example of an autophagosome is illustrated by the electron micrograph in Figure 4; shown are autophagosomes from a WEHI 7.2 T cell stably expressing Bcl-2 and cultured in normal growth media containing dexamethasone. Glucocorticoids promote autophagy (Laane et al. 2009; Swerdlow et al. 2008), and this process is most evident when apoptosis is inhibited by Bcl-2 (Swerdlow et al. 2008). 
A

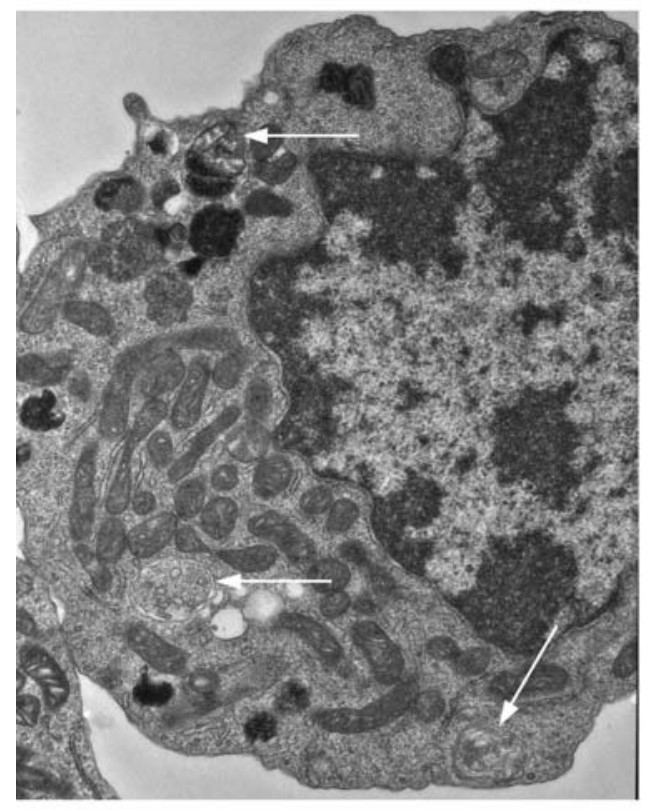

B

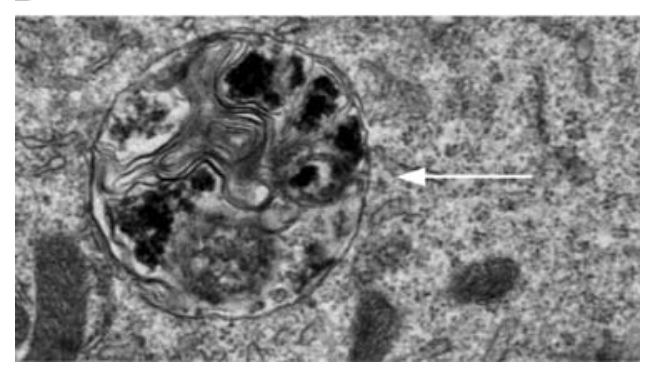

Figure 4. Electron micrograph of a malignant $\mathrm{T}$ cell undergoing autophagy. $\mathrm{T}$ cells that ectopically express Bcl-2 readily undergo autophagy in the presence of glucocorticoid hormones. Here, WEHI7.2 T cells stably expressing Bcl-2 (to inhibit apoptosis) were treated with $10^{-6} \mathrm{M}$ dexamethasone for 72 hours and visualized by electron microscopy. $(A)$ An electron micrograph of a single cell or $(B)$ a region from within a cell. Examples of autophagosomes are shown next to the arrows.

Methods for the detection of autophagy are very well described by Klionsky and colleagues (Klionsky et al. 2008). Briefly, the most common method of analysis is the assessment of microtubule-associated protein-1 light chain-3 (LC3) by immunoblotting. LC3 is considered a marker for autophagy when it is proteolytically
Apoptosis and Autophagy

processed and conjugated to phosphatidylethanolamine (LC3II). GFP-tagged LC3 is commonly transfected into cells to detect LC3 aggregates or punctate GFP-LC3II, which is indicative of autophagosome formation. A second marker of autophagy is p62 degradation. The signaling adaptor p62, which is implicated in the activation of the transcription factor $\mathrm{NF \kappa B}$, is rapidly degraded by autolysosomes. Thus, p62 expression is inversely correlated with the conversion of LC3I to LC3II. Finally, as previously stated and shown in Figure 4, autophagosome formation can be readily visualized by electron microscopy, although this method is less amenable than others to quantitative interpretation.

\section{Autophagy Induction by ER Stress Pathways}

The link between calcium and autophagy was initially discovered by several groups reporting that autophagy could be provoked by ER stress (Bernales et al. 2006; Ogata et al. 2006; Yorimitsu et al. 2006). For example, both thapsigargin and tunicamycin stimulate autophagy (Ogata et al. 2006). ER stress affects Autophagy-Related Genes (atg), which are evolutionarily conserved and indispensable for autophagy in many cell systems. In yeast, the transcription factor Hac-1 (an ortholog of the ER-stress mammalian XBP-1) transactivates atg8 during the unfolded protein response (Bernales et al. 2006). Other studies have shown that mutations in ER stress-related proteins such as PERK or EIF2 $\alpha$ can inhibit autophagy (Kouroku et al. 2007). Further, knockout of several atg genes prevents autophagy-mediated survival in the presence of tunicamycin (Ogata et al. 2006). While these data indisputably demonstrate that ER stress induces autophagy, a direct role for calcium had not been implicated at this point in time.

\section{Autophagy Regulation by Calcium Signaling}

Direct evidence that calcium signaling stimulates autophagy was first reported by Jaattela and colleagues (Hoyer-Hansen et al. 2007). They demonstrated that ER calcium mobilization induces autophagy when stimulated by 
agents such as vitamin $\mathrm{D}$, ionomycin, and thapsigargin. Moreover, GFP-LC3 aggregates were inhibited with BAPTA-AM, suggesting that autophagosome formation was calcium dependent. They provided further evidence that autophagy occurred by the calcium-dependent activation of AMP activated protein kinase, which required upstream activation of the calcium/calmodulin kinase kinase $\beta$. AMPK is activated during nutrient deprivation to inhibit activity of the target of rapamycin (mTOR), a negative regulator of autophagy (Hoyer-Hansen and Jaattela 2007). Further evidence supporting a direct role for calcium in the induction of autophagy was the finding that calcium phosphate precipitates could induce autophagy when transfected into HEK293 cells (Gao et al. 2008). Importantly, autophagy mediated by calcium phosphate was also Beclin-dependent. Beclin is a newly discovered BH3-only protein that mediates autophagy by forming a complex between the class III PI3 kinase Vps34 and p150, which facilitates assembly of the autophagosome (Sinha and Levine 2008).

\section{Autophagy in the Context of T-cell Activation}

As previously described, significant contributions in the calcium field have been made by investigating signal transduction pathways in activated lymphocytes. Accordingly, autophagy may also be important for regulating lymphocyte activation. For example, T cells from atg5 knockout mice do not proliferate following ligation of the T-cell receptor, nor do they survive in the periphery (Pua et al. 2007), suggesting that autophagy is required for T-cell activation. Interestingly, it was shown that T-cell activation increases autophagy by NFkB-dependent transcription of Beclin-1 (Copetti et al. 2009a; Copetti et al. 2009b). In this study, the authors provide evidence that $\mathrm{NF} \kappa \mathrm{B}$ directly binds to the Beclin-1 promoter following activation of Jurkat $\mathrm{T}$ cells. Although a direct link has not been observed, it is possible that calciumdependent activation of calcineurin stimulates this process, thus implicating a role for calcium in Beclin-1 transcription and autophagy.
In addition to producing $\mathrm{IP}_{3}$, T-cell activation also generates reactive oxygen species (Devadas et al. 2002; Hildeman et al. 2003). Thiol groups are found on $\mathrm{IP}_{3}$ Rs and ryanodine receptors, and oxidation of both calcium channels favors their opening (Bootman et al. 1992; Bultynck et al. 2004; Joseph et al. 2006; Sun et al. 2001; Xia et al. 2000). Further, cyclic ADP ribose and NAADP govern redox reactions and are also endogenous ligands for ryanodine receptors and natural 2 nd messengers produced by T-cell activation (Fliegert et al. 2007; Guse 2009). These studies have implicated a role for reactive oxygen species in regulating calcium signals. Not surprisingly, reactive oxygen species also contribute to the induction of autophagy. For example, hydrogen peroxide directly facilitates formation of the autophagosome by oxidizing Atg4 (Scherz-Shouval et al. 2007). Another study demonstrated that neurons undergo autophagy when mitochondrial fission is induced by nitric oxide (Barsoum et al. 2006). This observation is attractive in light of the fact that nitric oxide protects cardiomyocytes from apoptosis. Together, these data suggest the possibility that oxidative metabolites function as signaling molecules by activating calcium and triggering autophagy in lymphocytes, although more definitive data is necessary to support this important conclusion.

\section{Autophagy Regulation by $\mathrm{IP}_{3} \mathrm{Rs}$}

There is now substantial evidence that autophagy is directly regulated by $\mathrm{IP}_{3}$ as well as by $\mathrm{IP}_{3}$ Rs. For example, inhibition of inositol monophosphate by agents such as lithium and L-690,330 induced autophagy (Sarkar et al. 2005; Sarkar and Rubinsztein 2006). Kroemer and colleagues first showed that $\mathrm{IP}_{3} \mathrm{Rs}$ act as inhibitors of autophagy by demonstrating that knocking down $\mathrm{IP}_{3}$ Rs or inhibiting their channel activity was sufficient to induce conversion of LC3I to LC3II. (Criollo et al. 2007). Moreover, Beclin-1 is in complex with $\mathrm{IP}_{3}$ Rs along with Bcl-2 and perturbation of the Beclin- $\mathrm{IP}_{3-}$ $\mathrm{R}-\mathrm{Bcl}-2$ interaction with Xestospongin $\mathrm{B}$ or RNA interference is sufficient for autophagy to occur (Vicencio et al. 2009). Additionally, 
phosphorylation of Beclin promotes its dissociation from Bcl-xL in order to induce autophagy (Zalckvar et al. 2009). Interestingly, inhibition of $\mathrm{IP}_{3}$ Rs or siRNA knockdown of Beclin-1 did not affect ER luminal calcium as measured in aequorin-expressing cells (Criollo et al. 2007; Vicencio et al. 2009). However, because Xestospongin significantly inhibited calcium responses following stimulation with histamine, it is possible that a lack of calcium release promotes autophagy without altering steady state levels under these conditions. Nevertheless, these findings indicate a role for calcium channels and signaling in the induction of autophagy.

\section{CONCLUDING REMARKS}

Calcium is a dynamic signal transducing ion that is absolutely required for life. Slight alterations in the frequency and/or amplitude of a calcium signal can lead to apoptosis or autophagy by numerous mechanisms. In addition, abnormal signaling not only alters calcium homeostasis in cells, but may contribute to several pathogenic states such as cancer, heart failure, diabetes, and Alzheimer's disease (Berridge 2003; Berridge 2010; Huang et al. 2010; Luciani et al. 2009; Roderick and Cook 2008). It is therefore essential to understand the pathways by which calcium regulates life and death decisions, as they will not only provide insight into normal cell physiology, but may also facilitate the development of novel targets and treatments for chronic diseases.

\section{ACKNOWLEDGMENTS}

We thank Karen McColl for editing and proofreading this manuscript as well as Hisashi Fujioka of the electron microscopy core facility at Case Western Reserve University.

\section{REFERENCES}

Altamirano F, Oyarce C, Silva P, Toyos M, Wilson C, Lavandero S, Uhlen P, Estrada M. 2009. Testosterone induces cardiomyocyte hypertrophy through mammalian target of rapamycin complex 1 pathway. J Endocrinol 202: 299-307.
An J, Chen Y, Huang Z. 2004. Critical upstream signals of cytochrome $\mathrm{C}$ release induced by a novel $\mathrm{Bcl}-2$ inhibitor. J Biol Chem 279: 19133-19140.

Andreka P, Nadhazi Z, Muzes G, Szantho G, Vandor L, Konya L, Turner MS, Tulassay Z, Bishopric NH. 2004. Possible therapeutic targets in cardiac myocyte apoptosis. Curr Pharm Des 10: 2445-2461.

Annis MG, Zamzami N, Zhu W, Penn LZ, Kroemer G, Leber B, Andrews DW. 2001. Endoplasmic reticulum localized Bcl-2 prevents apoptosis when redistribution of cytochrome $\mathrm{c}$ is a late event. Oncogene 20: 1939-1952.

Aranguiz-Urroz P, Soto D, Contreras A, Troncoso R, Chiong M, Montenegro J, Venegas D, Smolic C, Ayala P, Thomas WG, et al. 2009. Differential participation of angiotensin II type 1 and 2 receptors in the regulation of cardiac cell death triggered by angiotensin II. Am J Hypertens 22: 569-576.

Ashwell JD, Lu FW, Vacchio MS. 2000. Glucocorticoids in T cell development and function. Annu Rev Immunol 18: 309-345.

Assefa Z, Bultynck G, Szlufcik K, Nadif Kasri N, Vermassen E, Goris J, Missiaen L, Callewaert G, Parys JB, De Smedt H. 2004. Caspase-3-induced truncation of type 1 inositol trisphosphate receptor accelerates apoptotic cell death and induces inositol trisphosphate-independent calcium release during apoptosis. J Biol Chem 279: 43227-43236.

Baffy G, Miyashita T, Williamson JR, Reed JC. 1993. Apoptosis induced by withdrawal of interleukin-3 (IL-3) from an IL-3-dependent hematopoietic cell line is associated with repartitioning of intracellular calcium and is blocked by enforced Bcl-2 oncoprotein production. I Biol Chem 268: 6511-6519.

Barouch LA, Harrison RW, Skaf MW, Rosas GO, Cappola TP, Kobeissi ZA, Hobai IA, Lemmon CA, Burnett AL, O’Rourke B, et al. 2002. Nitric oxide regulates the heart by spatial confinement of nitric oxide synthase isoforms. Nature 416: 337-339.

Barsoum MJ, Yuan H, Gerencser AA, Liot G, Kushnareva Y, Graber S, Kovacs I, Lee WD, Waggoner J, Cui J, et al. 2006. Nitric oxide-induced mitochondrial fission is regulated by dynamin-related GTPases in neurons. Embo $J$ 25: 3900-3911.

Baus E, Andris F, Dubois PM, Urbain J, Leo O. 1996. Dexamethasone inhibits the early steps of antigen receptor signaling in activated $\mathrm{T}$ lymphocytes. J Immunol 156: 4555-4561.

Benten WP, Lieberherr M, Sekeris CE, Wunderlich F. 1997. Testosterone induces $\mathrm{Ca}^{2+}$ influx via non-genomic surface receptors in activated T cells. FEBS Lett 407: 211-214.

Berg I, Potter BV, Mayr GW, Guse AH. 2000. Nicotinic acid adenine dinucleotide phosphate $(\operatorname{NAADP}(+))$ is an essential regulator of T-lymphocyte $\mathrm{Ca}^{2+}$-signaling. J Cell Biol 150: 581-588.

Bernales S, McDonald KL, Walter P. 2006. Autophagy counterbalances endoplasmic reticulum expansion during the unfolded protein response. PLoS Biol 4: e423.

Berridge MJ. 1997. Lymphocyte activation in health and disease. Crit Rev Immunol 17: 155-178.

Berridge MJ. 2003. Cardiac calcium signalling. Biochem Soc Trans 31: 930-933. 
M.W. Harr and C.W. Distelhorst

Berridge MJ. 2010. Calcium hypothesis of Alzheimer's disease. Pflugers Arch 459: 441-449.

Bian X, Hughes FM Jr, Huang Y, Cidlowski JA, Putney JW Jr. 1997. Roles of cytoplasmic $\mathrm{Ca}^{2+}$ and intracellular $\mathrm{Ca}^{2+}$ stores in induction and suppression of apoptosis in $\mathrm{S} 49$ cells. Am J Physiol 272: C1241-1249.

Bootman MD, Taylor CW, Berridge MJ. 1992. The thiol reagent, thimerosal, evokes $\mathrm{Ca}^{2+}$ spikes in HeLa cells by sensitizing the inositol 1,4,5-trisphosphate receptor. $J$ Biol Chem 267: 25113-25119.

Brooks KJ, Hargreaves IP, Bates TE. 2000. Nitricoxide-induced inhibition of mitochondrial complexes following aglycaemic hypoxia in neonatal cortical rat brain slices. Dev Neurosci 22: 359-365.

Bultynck G, Szlufcik K, Kasri NN, Assefa Z, Callewaert G, Missiaen L, Parys JB, De Smedt H. 2004. Thimerosal stimulates $\mathrm{Ca}^{2+}$ flux through inositol 1,4,5-trisphosphate receptor type 1 , but not type 3 , via modulation of an isoform-specific $\mathrm{Ca}^{2+}$-dependent intramolecular interaction. Biochem J 381: 87-96.

Cameron AM, Steiner JP, Roskams AJ, Ali SM, Ronnett GV, Snyder SH. 1995. Calcineurin associated with the inositol 1,4,5-trisphosphate receptor-FKBP12 complex modulates $\mathrm{Ca}^{2+}$ flux. Cell 83: 463-472.

Cante-Barrett K, Gallo EM, Winslow MM, Crabtree GR. 2006. Thymocyte negative selection is mediated by protein kinase C- and $\mathrm{Ca}^{2+}$-dependent transcriptional induction of bim. J Immunol 176: 2299-2306.

Chae HJ, Kim HR, Xu C, Bailly-Maitre B, Krajewska M, Krajewski S, Banares S, Cui J, Digicaylioglu M, Ke N, et al. 2004. BI-1 regulates an apoptosis pathway linked to endoplasmic reticulum stress. Mol Cell 15: 355-366.

Chai J, Xiong Q, Zhang P, Zheng R, Peng J, Jiang S. 2009. Induction of $\mathrm{Ca}^{2+}$ signal mediated apoptosis and alteration of $\mathrm{IP}_{3} \mathrm{R} 1$ and SERCA1 expression levels by stress hormone in differentiating $\mathrm{C} 2 \mathrm{C} 12$ myoblasts. Gen Comp Endocrinol 166: 241-249.

Chen R, Valencia I, Zhong F, McColl KS, Roderick HL, Bootman MD, Berridge MJ, Conway SJ, Holmes AB, Mignery GA, et al. 2004. Bcl-2 functionally interacts with inositol 1,4,5-trisphosphate receptors to regulate calcium release from the ER in response to inositol 1,4,5-trisphosphate. J Cell Biol 166: 193-203.

Cheng EH, Wei MC, Weiler S, Flavell RA, Mak TW, Lindsten T, Korsmeyer SJ. 2001. BCL-2, BCL-X(L) sequester BH3 domain-only molecules preventing BAX- and BAKmediated mitochondrial apoptosis. Mol Cell 8: 705-711.

Chipuk JE, Moldoveanu T, Llambi F, Parsons MJ, Green DR. 2010. The BCL-2 family reunion. Mol Cell 37: 299-310.

Cigola E, Kajstura J, Li B, Meggs LG, Anversa P. 1997. Angiotensin II activates programmed myocyte cell death in vitro. Exp Cell Res 231: 363-371.

Cohen JJ, Duke RC. 1984. Glucocorticoid activation of a calcium-dependent endonuclease in thymocyte nuclei leads to cell death. J Immunol 132: 38-42.

Copetti T, Bertoli C, Dalla E, Demarchi F, Schneider C. 2009a. p65/RelA modulates BECN1 transcription and autophagy. Mol Cell Biol 29: 2594-2608.

Copetti T, Demarchi F, Schneider C. 2009b. p65/RelA binds and activates the beclin 1 promoter. Autophagy 5: 858-859.
Cory S, Adams JM. 2002. The Bcl2 family: regulators of the cellular life-or-death switch. Nat Rev Cancer 2: 647-656.

Criollo A, Maiuri MC, Tasdemir E, Vitale I, Fiebig AA, Andrews D, Molgo J, Diaz J, Lavandero S, Harper F, et al. 2007. Regulation of autophagy by the inositol trisphosphate receptor. Cell Death Differ 14: 1029-1039.

Dammermann W, Zhang B, Nebel M, Cordiglieri C, Odoardi F, Kirchberger T, Kawakami N, Dowden J, Schmid F, Dornmair K, et al. 2009. NAADP-mediated $\mathrm{Ca}^{2+}$ signaling via type 1 ryanodine receptor in $\mathrm{T}$ cells revealed by a synthetic NAADP antagonist. Proc Natl Acad Sci U S A 106: 10678-10683.

Davidson SM, Duchen MR. 2006. Calcium microdomains and oxidative stress. Cell Calcium 40: 561-574.

Davis MC, McColl KS, Zhong F, Wang Z, Malone MH, Distelhorst CW. 2008. Dexamethasone-induced inositol 1,4,5-trisphosphate receptor elevation in murine lymphoma cells is not required for dexamethasone-mediated calcium elevation and apoptosis. J Biol Chem 283: $10357-$ 10365.

Dedkova EN, Blatter LA. 2005. Modulation of mitochondrial $\mathrm{Ca}^{2+}$ by nitric oxide in cultured bovine vascular endothelial cells. Am J Physiol Cell Physiol 289: C836-845.

DeSouza N, Reiken S, Ondrias K, Yang YM, Matkovich S, Marks AR. 2002. Protein kinase A and two phosphatases are components of the inositol 1,4,5-trisphosphate receptor macromolecular signaling complex. J Biol Chem 277: 39397-39400.

Devadas S, Zaritskaya L, Rhee SG, Oberley L, Williams MS. 2002. Discrete generation of superoxide and hydrogen peroxide by $\mathrm{T}$ cell receptor stimulation: selective regulation of mitogen-activated protein kinase activation and fas ligand expression. J Exp Med 195: 59-70.

Diaz-Prieto N, Herrera-Peco I, de Diego AM, Ruiz-Nuno A, Gallego-Sandin S, Lopez MG, Garcia AG, Cano-Abad MF. 2008. Bcl-2 mitigates $\mathrm{Ca}^{2+}$ entry and mitochondrial $\mathrm{Ca}^{2+}$ overload through downregulation of L-type $\mathrm{Ca}^{2+}$ channels in PC12 cells. Cell Calcium 44: 339-352.

Dimmeler S, Haendeler J, Nehls M, Zeiher AM. 1997. Suppression of apoptosis by nitric oxide via inhibition of interleukin-1beta-converting enzyme (ICE)-like and cysteine protease protein (CPP)-32-like proteases. J Exp Med 185: 601-607.

Dremina ES, Sharov VS, Kumar K, Zaidi A, Michaelis EK, Schoneich C. 2004. Anti-apoptotic protein Bcl-2 interacts with and destabilizes the sarcoplasmic/endoplasmic reticulum $\mathrm{Ca}^{2+}$-ATPase (SERCA). Biochem J 383: 361-370.

Dremina ES, Sharov VS, Schoneich C. 2006. Displacement of SERCA from SR lipid caveolae-related domains by Bcl-2: a possible mechanism for SERCA inactivation. Biochemistry 45: 175-184.

Eckenrode EF, Yang J, Velmurugan GV, Foskett JK, White C. 2010. Apoptosis protection by Mcl-1 and Bcl-2 modulation of inositol 1,4,5-trisphosphate receptor-dependent $\mathrm{Ca}^{2+}$ signaling. J Biol Chem 285: 13678-13684.

Erin N, Bronson SK, Billingsley ML. 2003. Calciumdependent interaction of calcineurin with $\mathrm{Bcl}-2$ in neuronal tissue. Neuroscience 117: 541-555. 
Estrada M, Varshney A, Ehrlich BE. 2006. Elevated testosterone induces apoptosis in neuronal cells. J Biol Chem 281: 25492-25501.

Fliegert R, Gasser A, Guse AH. 2007. Regulation of calcium signalling by adenine-based second messengers. Biochem Soc Trans 35: 109-114.

Foyouzi-Youssefi R, Arnaudeau S, Borner C, Kelley WL, Tschopp J, Lew DP, Demaurex N, Krause KH. 2000. Bcl-2 decreases the free $\mathrm{Ca}^{2+}$ concentration within the endoplasmic reticulum. Proc Natl Acad Sci U S A 97: 5723-5728.

Galione A, Petersen OH. 2005. The NAADP receptor: new receptors or new regulation? Mol Interv 5: 73-79.

Gallo EM, Cante-Barrett K, Crabtree GR. 2006. Lymphocyte calcium signaling from membrane to nucleus. Nat Immunol 7: 25-32.

Gao W, Ding WX, Stolz DB, Yin XM. 2008. Induction of macroautophagy by exogenously introduced calcium. Autophagy 4: 754-761.

Germain M, Mathai JP, McBride HM, Shore GC. 2005. Endoplasmic reticulum BIK initiates DRP1-regulated remodelling of mitochondrial cristae during apoptosis. Embo J 24: 1546-1556.

Goldenberg I, Grossman E, Jacobson KA, Shneyvays V, Shainberg A. 2001. Angiotensin II-induced apoptosis in rat cardiomyocyte culture: a possible role of AT1 and AT2 receptors. J Hypertens 19: 1681-1689.

Gradman AH. 2009. Role of angiotensin II type 1 receptor antagonists in the treatment of hypertension in patients aged $>$ or $=65$ years. Drugs Aging 26: 751-767.

Green DR. 2003. Overview: apoptotic signaling pathways in the immune system. Immunol Rev 193: 5-9.

Green DR. 2005. Apoptotic pathways: ten minutes to dead. Cell 121: 671-674.

Guse AH. 2009. Second messenger signaling: multiple receptors for NAADP. Curr Biol 19: R521-523.

Guse AH, da Silva CP, Berg I, Skapenko AL, Weber K, Heyer P, Hohenegger M, Ashamu GA, Schulze-Koops H, Potter BV, et al. 1999. Regulation of calcium signalling in T lymphocytes by the second messenger cyclic ADP-ribose. Nature 398: 70-73.

Hajnoczky G, Csordas G, Das S, Garcia-Perez C, Saotome M, Sinha Roy S, Yi M. 2006. Mitochondrial calcium signalling and cell death: approaches for assessing the role of mitochondrial $\mathrm{Ca}^{2+}$ uptake in apoptosis. Cell Calcium 40: $553-560$.

Hanson CJ, Bootman MD, Distelhorst CW, Wojcikiewicz RJ, Roderick HL. 2008. Bcl-2 suppresses $\mathrm{Ca}^{2+}$ release through inositol 1,4,5-trisphosphate receptors and inhibits $\mathrm{Ca}^{2+}$ uptake by mitochondria without affecting ER calcium store content. Cell Calcium 44: 324-338.

Hanson CJ, Bootman MD, Roderick HL. 2004. Cell signalling: $\mathrm{IP}_{3}$ receptors channel calcium into cell death. Curr Biol 14: R933-935.

Harr MW, Rong Y, Bootman MD, Roderick HL, Distelhorst CW. 2009. Glucocorticoid-mediated inhibition of Lck modulates the pattern of $\mathrm{T}$ cell receptor-induced calcium signals by down-regulating inositol 1,4,5-trisphosphate receptors. J Biol Chem 284: 31860-31871.
Herold MJ, McPherson KG, Reichardt HM. 2006. Glucocorticoids in T cell apoptosis and function. Cell Mol Life Sci 63: 60-72.

Hildeman DA, Mitchell T, Kappler J, Marrack P. 2003. T cell apoptosis and reactive oxygen species. J Clin Invest 111: $575-581$.

Hirota J, Furuichi T, Mikoshiba K. 1999. Inositol 1,4,5-trisphosphate receptor type 1 is a substrate for caspase-3 and is cleaved during apoptosis in a caspase-3-dependent manner. J Biol Chem 274: 34433-34437.

Hogquist KA. 2001. Signal strength in thymic selection and lineage commitment. Curr Opin Immunol 13: 225-231.

Hoyer-Hansen M, Bastholm L, Szyniarowski P, Campanella M, Szabadkai G, Farkas T, Bianchi K, Fehrenbacher N, Elling F, Rizzuto R, et al. 2007. Control of macroautophagy by calcium, calmodulin-dependent kinase kinasebeta, and Bcl-2. Mol Cell 25: 193-205.

Hoyer-Hansen M, Jaattela M. 2007. AMP-activated protein kinase: a universal regulator of autophagy? Autophagy 3: 381-383.

Huang CJ, Gurlo T, Haataja L, Costes S, Daval M, Ryazantsev S, Wu X, Butler AE, Butler PC. 2010. Calcium-activated calpain-2 is a mediator of beta cell dysfunction and apoptosis in type 2 diabetes. J Biol Chem 285: 339-348.

Jamieson CA, Yamamoto KR. 2000. Crosstalk pathway for inhibition of glucocorticoid-induced apoptosis by $\mathrm{T}$ cell receptor signaling. Proc Natl Acad Sci U S A 97: 73197324.

Jayaraman T, Marks AR. 1997. T cells deficient in inositol 1,4,5-trisphosphate receptor are resistant to apoptosis. Mol Cell Biol 17: 3005-3012.

Jiao J, Huang X, Feit-Leithman RA, Neve RL, Snider W, Dartt DA, Chen DF. 2005. Bcl-2 enhances $\mathrm{Ca}^{2+}$ signaling to support the intrinsic regenerative capacity of CNS axons. Embo J 24: 1068-1078.

Joseph SK, Nakao SK, Sukumvanich S. 2006. Reactivity of free thiol groups in type-I inositol trisphosphate receptors. Biochem J 393: 575-582.

Kaiser N, Edelman IS. 1977. Calcium dependence of glucocorticoid-induced lymphocytolysis. Proc Natl Acad Sci U S A 74: 638-642.

Kajstura J, Cigola E, Malhotra A, Li P, Cheng W, Meggs LG, Anversa P. 1997. Angiotensin II induces apoptosis of adult ventricular myocytes in vitro. J Mol Cell Cardiol 29: $859-870$.

Khan SA, Hare JM. 2003. The role of nitric oxide in the physiological regulation of $\mathrm{Ca}^{2+}$ cycling. Curr Opin Drug Discov Devel 6: 658-666.

Kim HR, Lee GH, Ha KC, Ahn T, Moon JY, Lee BJ, Cho SG, Kim S, Seo YR, Shin YJ, et al. 2008. Bax Inhibitor-1 Is a $\mathrm{pH}$-dependent regulator of $\mathrm{Ca}^{2+}$ channel activity in the endoplasmic reticulum. J Biol Chem 283: 15946-15955.

Klee M, Pallauf K, Alcala S, Fleischer A, Pimentel-Muinos FX. 2009. Mitochondrial apoptosis induced by BH3-only molecules in the exclusive presence of endoplasmic reticular Bak. Embo J 28: 1757-1768.

Klionsky DJ, Abeliovich H, Agostinis P, Agrawal DK, Aliev G, Askew DS, Baba M, Baehrecke EH, Bahr BA, Ballabio A, et al. 2008. Guidelines for the use and interpretation of assays for monitoring autophagy in higher eukaryotes. Autophagy 4: 151-175. 
M.W. Harr and C.W. Distelhorst

Kockskamper J, Zima AV, Roderick HL, Pieske B, Blatter LA, Bootman MD. 2008. Emerging roles of inositol 1,4,5-trisphosphate signaling in cardiac myocytes. $J \mathrm{Mol}$ Cell Cardiol 45: 128-147.

Kouroku Y, Fujita E, Tanida I, Ueno T, Isoai A, Kumagai H, Ogawa S, Kaufman RJ, Kominami E, Momoi T. 2007. ER stress (PERK/eIF2alpha phosphorylation) mediates the polyglutamine-induced LC3 conversion, an essential step for autophagy formation. Cell Death Differ 14: 230-239.

Kruman II, Mattson MP. 1999. Pivotal role of mitochondrial calcium uptake in neural cell apoptosis and necrosis. J Neurochem 72: 529-540.

Laane E, Tamm KP, Buentke E, Ito K, Kharaziha P, Oscarsson J, Corcoran M, Bjorklund AC, Hultenby K, Lundin J, et al. 2009. Cell death induced by dexamethasone in lymphoid leukemia is mediated through initiation of autophagy. Cell Death Differ 16: 1018-1029.

Lam M, Dubyak G, Chen L, Nunez G, Miesfeld RL, Distelhorst CW. 1994. Evidence that BCL-2 represses apoptosis by regulating endoplasmic reticulum-associated $\mathrm{Ca}^{2+}$ fluxes. Proc Natl Acad Sci U S A 91: 6569-6573.

Lam M, Dubyak G, Distelhorst CW. 1993. Effect of glucocorticosteroid treatment on intracellular calcium homeostasis in mouse lymphoma cells. Mol Endocrinol 7: 686-693.

Latour S, Veillette A. 2001. Proximal protein tyrosine kinases in immunoreceptor signaling. Curr Opin Immunol 13: 299-306.

Levine B, Klionsky DJ. 2004. Development by self-digestion: molecular mechanisms and biological functions of autophagy. Dev Cell 6: 463-477.

Levine B, Yuan J. 2005. Autophagy in cell death: an innocent convict? J Clin Invest 115: 2679-2688.

Lewis RS. 2001. Calcium signaling mechanisms in T lymphocytes. Annu Rev Immunol 19: 497-521.

Li C, Wang X, Vais H, Thompson CB, Foskett JK, White C. 2007. Apoptosis regulation by $\mathrm{Bcl}-\mathrm{x}(\mathrm{L})$ modulation of mammalian inositol 1,4,5-trisphosphate receptorchannel isoform gating. Proc Natl Acad Sci U S A 104: 1256512570.

Lowenberg M, Tuynman J, Bilderbeek J, Gaber T, Buttgereit F, van Deventer S, Peppelenbosch M, Hommes D. 2005. Rapid immunosuppressive effects of glucocorticoids mediated through Lck and Fyn. Blood 106: 1703-1710.

Lu J, Quearry B, Harada H. 2006. p38-MAP kinase activation followed by BIM induction is essential for glucocorticoid-induced apoptosis in lymphoblastic leukemia cells. FEBS Lett 580: 3539-3544.

Luciani DS, Gwiazda KS, Yang TL, Kalynyak TB, Bychkivska Y, Frey MH, Jeffrey KD, Sampaio AV, Underhill TM, Johnson JD. 2009. Roles of $\mathrm{IP}_{3} \mathrm{R}$ and $\mathrm{RyR} \mathrm{Ca}^{2+}$ channels in endoplasmic reticulum stress and beta-cell death. Diabetes 58: $422-432$.

Ludwinski MW, Sun J, Hilliard B, Gong S, Xue F, Carmody RJ, DeVirgiliis J, Chen YH. 2009. Critical roles of Bim in T cell activation and T cell-mediated autoimmune inflammation in mice. J Clin Invest 119: 1706-1713.

Magnelli L, Cinelli M, Turchetti A, Chiarugi VP. 1994. Bcl-2 overexpression abolishes early calcium waving preceding apoptosis in NIH-3T3 murine fibroblasts. Biochem Biophys Res Commun 204: 84-90.

Mandic A, Hansson J, Linder S, Shoshan MC. 2003. Cisplatin induces endoplasmic reticulum stress and nucleus-independent apoptotic signaling. J Biol Chem 278: 9100-9106.

Mariathasan S, Bachmann MF, Bouchard D, Ohteki T, Ohashi PS. 1998. Degree of TCR internalization and $\mathrm{Ca}^{2+}$ flux correlates with thymocyte selection. J Immunol 161: 6030-6037.

Massion PB, Feron O, Dessy C, Balligand JL. 2003. Nitric oxide and cardiac function: ten years after, and continuing. Circ Res 93: 388-398.

Mathai JP, Germain M, Shore GC. 2005. BH3-only BIK regulates BAX,BAK-dependent release of $\mathrm{Ca}^{2+}$ from endoplasmic reticulum stores and mitochondrial apoptosis during stress-induced cell death. J Biol Chem 280: 2382923836.

Mattiazzi A. 1997. Positive inotropic effect of angiotensin II. Increases in intracellular $\mathrm{Ca}^{2+}$ or changes in myofilament $\mathrm{Ca}^{2+}$ responsiveness? J Pharmacol Toxicol Methods 37: 205-214.

McConkey DJ, Nicotera P, Hartzell P, Bellomo G, Wyllie AH, Orrenius S. 1989. Glucocorticoids activate a suicide process in thymocytes through an elevation of cytosolic $\mathrm{Ca}^{2+}$ concentration. Arch Biochem Biophys 269: 365-370.

Minagawa N, Kruglov EA, Dranoff JA, Robert ME, Gores GJ, Nathanson MH. 2005. The anti-apoptotic protein Mcl-1 inhibits mitochondrial $\mathrm{Ca}^{2+}$ signals. J Biol Chem 280: 33637-33644.

Mizushima N. 2007. Autophagy: process and function. Genes Dev 21: 2861-2873.

Mizushima N, Levine B, Cuervo AM, Klionsky DJ. 2008. Autophagy fights disease through cellular self-digestion. Nature 451: 1069-1075.

Morishima N, Nakanishi K, Takenouchi H, Shibata T, Yasuhiko Y. 2002. An endoplasmic reticulum stress-specific caspase cascade in apoptosis. Cytochrome c-independent activation of caspase- 9 by caspase-12. J Biol Chem 277: 34287-34294.

Morishima N, Nakanishi K, Tsuchiya K, Shibata T, Seiwa E. 2004. Translocation of Bim to the endoplasmic reticulum (ER) mediates ER stress signaling for activation of caspase-12 during ER stress-induced apoptosis. J Biol Chem 279: 50375-50381.

Mustelin T, Tasken K. 2003. Positive and negative regulation of T-cell activation through kinases and phosphatases. Biochem J 371: 15-27.

Nakagawa T, Yuan J. 2000. Cross-talk between two cysteine protease families. Activation of caspase-12 by calpain in apoptosis. J Cell Biol 150: 887-894.

Nakagawa T, Zhu H, Morishima N, Li E, Xu J, Yankner BA, Yuan J. 2000. Caspase-12 mediates endoplasmicreticulum-specific apoptosis and cytotoxicity by amyloid-beta. Nature 403: 98-103.

Norberg E, Gogvadze V, Ott M, Horn M, Uhlen P, Orrenius S, Zhivotovsky B. 2008. An increase in intracellular $\mathrm{Ca}^{2+}$ is required for the activation of mitochondrial calpain to release AIF during cell death. Cell Death Differ 15: 1857-1864. 
Nutt LK, Chandra J, Pataer A, Fang B, Roth JA, Swisher SG O'Neil RG, McConkey DJ. 2002a. Bax-mediated $\mathrm{Ca}^{2+}$ mobilization promotes cytochrome $\mathrm{c}$ release during apoptosis. J Biol Chem 277: 20301-20308.

Nutt LK, Pataer A, Pahler J, Fang B, Roth J, McConkey DJ, Swisher SG. 2002b. Bax and Bak promote apoptosis by modulating endoplasmic reticular and mitochondrial $\mathrm{Ca}^{2+}$ stores. J Biol Chem 277: 9219-9225.

Oakes SA, Scorrano L, Opferman JT, Bassik MC, Nishino M, Pozzan T, Korsmeyer SJ. 2005. Proapoptotic BAX and BAK regulate the type 1 inositol trisphosphate receptor and calcium leak from the endoplasmic reticulum. Proc Natl Acad Sci U S A 102: 105-110.

Ogata M, Hino S, Saito A, Morikawa K, Kondo S, Kanemoto S, Murakami T, Taniguchi M, Tanii I, Yoshinaga K, et al. 2006. Autophagy is activated for cell survival after endoplasmic reticulum stress. Mol Cell Biol 26: 9220-9231.

Orrenius S, McConkey DJ, Nicotera P. 1991. Role of calcium in toxic and programmed cell death. Adv Exp Med Biol 283: $419-425$.

Pacher P, Hajnoczky G. 2001. Propagation of the apoptotic signal by mitochondrial waves. Embo J 20: 4107-4121.

Palacios EH, Weiss A. 2004. Function of the Src-family kinases, Lck and Fyn, in T-cell development and activation. Oncogene 23: 7990-8000.

Palmer AE, Jin C, Reed JC, Tsien RY. 2004. Bcl-2-mediated alterations in endoplasmic reticulum $\mathrm{Ca}^{2+}$ analyzed with an improved genetically encoded fluorescent sensor. Proc Natl Acad Sci U S A 101: 17404-17409.

Palomeque J, Delbridge L, Petroff MV. 2009. Angiotensin II: a regulator of cardiomyocyte function and survival. Front Biosci 14: 5118-5133.

Pinton P, Ferrari D, Magalhaes P, Schulze-Osthoff K, Di Virgilio F, Pozzan T, Rizzuto R. 2000. Reduced loading of intracellular $\mathrm{Ca}^{2+}$ stores and downregulation of capacitative $\mathrm{Ca}^{2+}$ influx in Bcl-2-overexpressing cells. J Cell Biol 148: $857-862$.

Pinton P, Giorgi C, Siviero R, Zecchini E, Rizzuto R. 2008. Calcium and apoptosis: ER-mitochondria $\mathrm{Ca}^{2+}$ transfer in the control of apoptosis. Oncogene 27: 6407-6418.

Pua HH, Dzhagalov I, Chuck M, Mizushima N, He YW. 2007. A critical role for the autophagy gene Atg5 in T cell survival and proliferation. J Exp Med 204: 25-31.

Randriamampita C, Trautmann A. 2003. $\mathrm{Ca}^{2+}$ signals and T lymphocytes "New mechanisms and functions in $\mathrm{Ca}^{2+}$ signaling". Biol of the Cell 96: 69-78.

Rao RV, Castro-Obregon S, Frankowski H, Schuler M, Stoka V, del Rio G, Bredesen DE, Ellerby HM. 2002. Coupling endoplasmic reticulum stress to the cell death program. An Apaf-1-independent intrinsic pathway. J Biol Chem 277: $21836-21842$.

Razavi HM, Hamilton JA, Feng Q. 2005. Modulation of apoptosis by nitric oxide: implications in myocardial ischemia and heart failure. Pharmacol Ther 106: 147-162.

Rizzuto R, Pinton P, Ferrari D, Chami M, Szabadkai G, Magalhaes PJ, Di Virgilio F, Pozzan T. 2003. Calcium and apoptosis: facts and hypotheses. Oncogene 22: 86198627.
Roderick HL, Cook SJ. 2008. Ca ${ }^{2+}$ signalling checkpoints in cancer: remodelling $\mathrm{Ca}^{2+}$ for cancer cell proliferation and survival. Nat Rev Cancer 8: 361-375.

Rong Y, Distelhorst CW. 2007. Bcl-2 Protein Family Members: Versatile Regulators of Calcium Signaling in Cell Survival and Apoptosis. Annu Rev Physiol 70: 73-91.

Rong YP, Aromolaran AS, Bultynck G, Zhong F, Li X, McColl K, Matsuyama S, Herlitze S, Roderick HL, Bootman MD, et al. 2008. Targeting Bcl-2-IP 3 receptor interaction to reverse Bcl-2's inhibition of apoptotic calcium signals. Mol Cell 31: 255-265.

Rong YP, Bultynck G, Aromolaran AS, Zhong F, Parys JB, De Smedt H, Mignery GA, Roderick HL, Bootman MD, Distelhorst CW. 2009. The BH4 domain of Bcl-2 inhibits ER calcium release and apoptosis by binding the regulatory and coupling domain of the $\mathrm{IP}_{3}$ receptor. Proc Natl Acad Sci U S A 106: 14397-14402.

Sarkar S, Floto RA, Berger Z, Imarisio S, Cordenier A, Pasco M, Cook LJ, Rubinsztein DC. 2005. Lithium induces autophagy by inhibiting inositol monophosphatase. J Cell Biol 170: 1101-1111.

Sarkar S, Rubinsztein DC. 2006. Inositol and $\mathrm{IP}_{3}$ levels regulate autophagy: biology and therapeutic speculations. Autophagy 2: 132-134.

Scherz-Shouval R, Shvets E, Fass E, Shorer H, Gil L, Elazar Z. 2007. Reactive oxygen species are essential for autophagy and specifically regulate the activity of Atg4. Embo J 26: 1749-1760.

Schrodl K, Oelmez H, Edelmann M, Huber RM, Bergner A. 2009. Altered $\mathrm{Ca}^{2+}$-homeostasis of cisplatin-treated and low level resistant non-small-cell and small-cell lung cancer cells. Cell Oncol 31: 301-315.

Scorrano L, Oakes SA, Opferman JT, Cheng EH, Sorcinelli MD, Pozzan T, Korsmeyer SJ. 2003. BAX and BAK regulation of endoplasmic reticulum $\mathrm{Ca}^{2+}:$ a control point for apoptosis. Science 300: 135-139.

Sears CE, Bryant SM, Ashley EA, Lygate CA, Rakovic S, Wallis HL, Neubauer S, Terrar DA, Casadei B. 2003. Cardiac neuronal nitric oxide synthase isoform regulates myocardial contraction and calcium handling. Circ Res 92: e52-59.

Seo YW, Woo HN, Piya S, Moon AR, Oh JW, Yun CW, Kim KK, Min JY, Jeong SY, Chung S, et al. 2009. The cell death-inducing activity of the peptide containing Noxa mitochondrial-targeting domain is associated with calcium release. Cancer Res 69: 8356-8365.

Shibasaki F, Kondo E, Akagi T, McKeon F. 1997. Suppression of signalling through transcription factor NF-AT by interactions between calcineurin and Bcl-2. Nature 386: $728-731$.

Sinha S, Levine B. 2008. The autophagy effector Beclin 1: a novel BH3-only protein. Oncogene 27: S137-148

Splettstoesser F, Florea AM, Busselberg D. 2007. IP(3) receptor antagonist, 2-APB, attenuates cisplatin induced $\mathrm{Ca}^{2+}$-influx in HeLa-S3 cells and prevents activation of calpain and induction of apoptosis. Br J Pharmacol 151: 1176-1186.

Starr TK, Jameson SC, Hogquist KA. 2003. Positive and negative selection of T cells. Annu Rev Immunol 21: 139-176. 
M.W. Harr and C.W. Distelhorst

Sun J, Xu L, Eu JP, Stamler JS, Meissner G. 2001. Classes of thiols that influence the activity of the skeletal muscle calcium release channel. J Biol Chem 276: 15625-15630.

Swerdlow S, McColl K, Rong Y, Lam M, Gupta A, Distelhorst CW. 2008. Apoptosis inhibition by Bcl-2 gives way to autophagy in glucocorticoid-treated lymphocytes. Autophagy 4: 612-620.

Szalai G, Krishnamurthy R, Hajnoczky G. 1999. Apoptosis driven by IP(3)-linked mitochondrial calcium signals. Embo J 18: 6349-6361.

Szegezdi E, Fitzgerald U, Samali A. 2003. Caspase-12 and ER-stress-mediated apoptosis: the story so far. Ann N Y Acad Sci 1010: 186-194.

Szlufcik K, Missiaen L, Parys JB, Callewaert G, De Smedt H. 2006. Uncoupled $\mathrm{IP}_{3}$ receptor can function as a $\mathrm{Ca}^{2+}$ leak channel: cell biological and pathological consequences. Biol Cell 98: 1-14.

Tolosa E, Ashwell JD. 1999. Thymus-derived glucocorticoids and the regulation of antigen-specific T-cell development. Neuroimmunomodulation 6: 90-96.

Tsujimoto Y, Cossman J, Jaffe E, Croce CM. 1985. Involvement of the bcl-2 gene in human follicular lymphoma. Science 228: 1440-1443.

Tsunoda T, Koga H, Yokomizo A, Tatsugami K, Eto M, Inokuchi J, Hirata A, Masuda K, Okumura K, Naito S. 2005. Inositol 1,4,5-trisphosphate $\left(\mathrm{IP}_{3}\right)$ receptor type1 (IP3R1) modulates the acquisition of cisplatin resistance in bladder cancer cell lines. Oncogene 24: 1396-1402.

Van Laethem F, Baus E, Smyth LA, Andris F, Bex F, Urbain J, Kioussis D, Leo O. 2001. Glucocorticoids attenuate T cell receptor signaling. J Exp Med 193: 803-814.

Vanden Abeele F, Skryma R, Shuba Y, Van Coppenolle F, Slomianny C, Roudbaraki M, Mauroy B, Wuytack F, Prevarskaya N. 2002. Bcl-2-dependent modulation of $\mathrm{Ca}^{2+}$ homeostasis and store-operated channels in prostate cancer cells. Cancer Cell 1: 169-179.

Verbert L, Lee B, Kocks SL, Assefa Z, Parys JB, Missiaen L, Callewaert G, Fissore RA, De Smedt H, Bultynck G. 2008. Caspase-3-truncated type 1 inositol 1,4,5-trisphosphate receptor enhances intracellular $\mathrm{Ca}^{2+}$ leak and disturbs $\mathrm{Ca}^{2+}$ signalling. Biol Cell 100: 39-49.

Vicencio JM, Ibarra C, Estrada M, Chiong M, Soto D, Parra V, Diaz-Araya G, Jaimovich E, Lavandero S. 2006. Testosterone induces an intracellular calcium increase by a nongenomic mechanism in cultured rat cardiac myocytes. Endocrinology 147: 1386-1395.

Vicencio JM, Ortiz C, Criollo A, Jones AW, Kepp O, Galluzzi L, Joza N, Vitale I, Morselli E, Tailler M, et al. 2009. The inositol 1,4,5-trisphosphate receptor regulates autophagy through its interaction with Beclin 1. Cell Death Differ 16: 1006-1017.

Wang Z, Malone MH, He H, McColl KS, Distelhorst CW. 2003. Microarray analysis uncovers the induction of the proapoptotic $\mathrm{BH} 3$-only protein Bim in multiple models of glucocorticoid-induced apoptosis. J Biol Chem 278: 23861-23867.
Wei MC, Zong WX, Cheng EH, Lindsten T, Panoutsakopoulou V, Ross AJ, Roth KA, MacGregor GR, Thompson CB, Korsmeyer SJ. 2001. Proapoptotic BAX and BAK: a requisite gateway to mitochondrial dysfunction and death. Science 292: 727-730.

White C, Li C, Yang J, Petrenko NB, Madesh M, Thompson CB, Foskett JK. 2005. The endoplasmic reticulum gateway to apoptosis by $\mathrm{Bcl}-\mathrm{X}(\mathrm{L})$ modulation of the InsP3R. Nat Cell Biol 7: 1021-1028.

Willis SN, Fletcher JI, Kaufmann T, van Delft MF, Chen L, Czabotar PE, Ierino H, Lee EF, Fairlie WD, Bouillet P, et al. 2007. Apoptosis initiated when BH3 ligands engage multiple Bcl-2 homologs, not Bax or Bak. Science 315: 856-859.

Winslow MM, Crabtree GR. 2005. Immunology. Decoding calcium signaling. Science 307: 56-57.

Winslow MM, Neilson JR, Crabtree GR. 2003. Calcium signalling in lymphocytes. Curr Opin Immunol 15: 299-307.

Xia R, Stangler T, Abramson JJ. 2000. Skeletal muscle ryanodine receptor is a redox sensor with a well defined redox potential that is sensitive to channel modulators. J Biol Chem 275: 36556-36561.

Xu KY, Huso DL, Dawson TM, Bredt DS, Becker LC. 1999. Nitric oxide synthase in cardiac sarcoplasmic reticulum. Proc Natl Acad Sci U S A 96: 657-662.

Xu L, Kong D, Zhu L, Zhu W, Andrews DW, Kuo TH. 2007. Suppression of $\mathrm{IP}_{3}$-mediated calcium release and apoptosis by Bcl-2 involves the participation of protein phosphatase 1. Mol Cell Biochem 295: 153-165.

Yamada T, Horiuchi M, Dzau VJ. 1996. Angiotensin II type 2 receptor mediates programmed cell death. Proc Natl Acad Sci U S A 93: 156-160.

Yorimitsu T, Nair U, Yang Z, Klionsky DJ. 2006. Endoplasmic reticulum stress triggers autophagy. J Biol Chem 281: 30299-30304.

Zalckvar E, Berissi H, Eisenstein M, Kimchi A. 2009. Phosphorylation of Beclin 1 by DAP-kinase promotes autophagy by weakening its interactions with Bcl-2 and Bcl-XL. Autophagy 5: 720-722.

Zhang L, Li L, Liu H, Borowitz JL, Isom GE. 2009a. BNIP3 mediates cell death by different pathways following localization to endoplasmic reticulum and mitochondrion. Faseb J 23: 3405-3414.

Zhang S, Hisatsune C, Matsu-Ura T, Mikoshiba K. 2009b. G-protein-coupled receptor kinase-interacting proteins inhibit apoptosis by inositol 1,4,5-triphosphate receptormediated $\mathrm{Ca}^{2+}$ signal regulation. J Biol Chem 284:2915829169.

Zhong F, Davis MC, McColl KS, Distelhorst CW. 2006. Bcl-2 differentially regulates $\mathrm{Ca}^{2+}$ signals according to the strength of T cell receptor activation. J Cell Biol 172: 127-137.

Zong WX, Li C, Hatzivassiliou G, Lindsten T, Yu QC, Yuan J, Thompson CB. 2003. Bax and Bak can localize to the endoplasmic reticulum to initiate apoptosis. J Cell Biol 162: 59-69. 


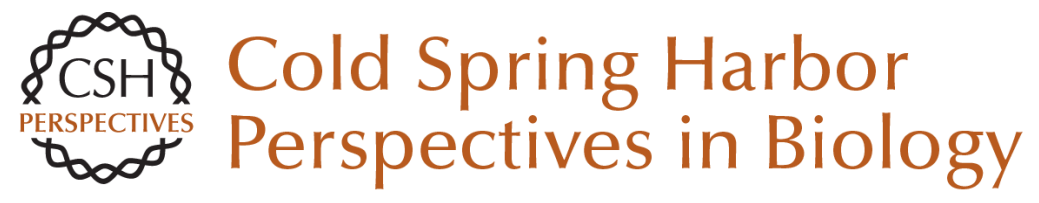

\title{
Apoptosis and Autophagy: Decoding Calcium Signals that Mediate Life or Death
}

\author{
Michael W. Harr and Clark W. Distelhorst
}

Cold Spring Harb Perspect Biol 2010; doi: 10.1101/cshperspect.a005579 originally published online September 8, 2010

\section{Subject Collection Calcium Signaling}

The Endoplasmic Reticulum-Plasma Membrane Junction: A Hub for Agonist Regulation of $\mathrm{Ca}^{2+}$ Entry

Hwei Ling Ong and Indu Suresh Ambudkar

Calcium-Handling Defects and Neurodegenerative

Disease

Sean Schrank, Nikki Barrington and Grace E. Stutzmann

Lysosomal $\mathrm{Ca}^{2+}$ Homeostasis and Signaling in Health and Disease

Emyr Lloyd-Evans and Helen Waller-Evans

$\mathrm{Ca}^{2+}$ Signaling in Exocrine Cells

Malini Ahuja, Woo Young Chung, Wei-Yin Lin, et al.

Functional Consequences of Calcium-Dependent Synapse-to-Nucleus Communication: Focus on Transcription-Dependent Metabolic Plasticity Anna M. Hagenston, Hilmar Bading and Carlos Bas-Orth

Identifying New Substrates and Functions for an Old Enzyme: Calcineurin

Jagoree Roy and Martha S. Cyert

Fundamentals of Cellular Calcium Signaling: A

Primer

Martin D. Bootman and Geert Bultynck
Primary Active $\mathrm{Ca}^{2+}$ Transport Systems in Health and Disease

Jialin Chen, Aljona Sitsel, Veronick Benoy, et al.

Signaling through $\mathrm{Ca}^{2+}$ Microdomains from

Store-Operated CRAC Channels

Pradeep Barak and Anant B. Parekh

Structural Insights into the Regulation of $\mathrm{Ca}^{2+}$

/Calmodulin-Dependent Protein Kinase II (CaMKII) Moitrayee Bhattacharyya, Deepti Karandur and John Kuriyan

Store-Operated Calcium Channels: From Function

to Structure and Back Again Richard S. Lewis

Bcl-2-Protein Family as Modulators of $\mathrm{IP}_{3}$

Receptors and Other Organellar $\mathrm{Ca} 2+$ Channels Hristina Ivanova, Tim Vervliet, Giovanni Monaco, et al.

Calcium Signaling in Cardiomyocyte Function Guillaume Gilbert, Kateryna Demydenko, Eef Dries, et al.

Cytosolic $\mathrm{Ca}^{2+}$ Buffers Are Inherently $\mathrm{Ca}^{2+}$ Signal Modulators Beat Schwaller

For additional articles in this collection, see http://cshperspectives.cshlp.org/cgi/collection/

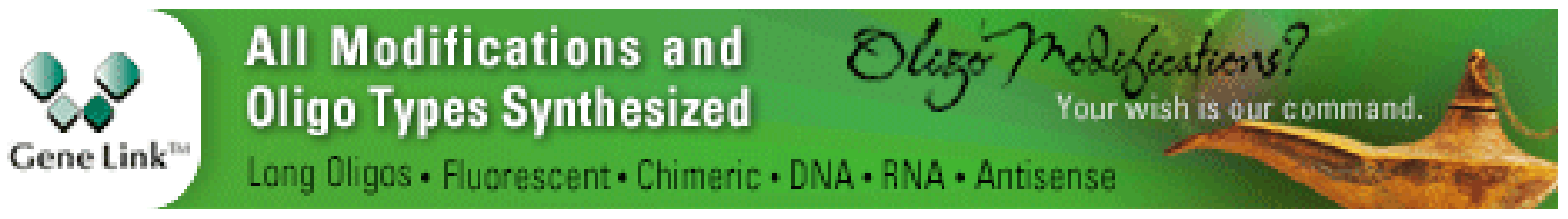


Role of Two-Pore Channels in Embryonic Development and Cellular Differentiation Sarah E. Webb, Jeffrey J. Kelu and Andrew L. Miller

\section{Organellar Calcium Handling in the Cellular \\ Reticular Network}

Wen-An Wang, Luis B. Agellon and Marek Michalak

For additional articles in this collection, see http://cshperspectives.cshlp.org/cgi/collection/

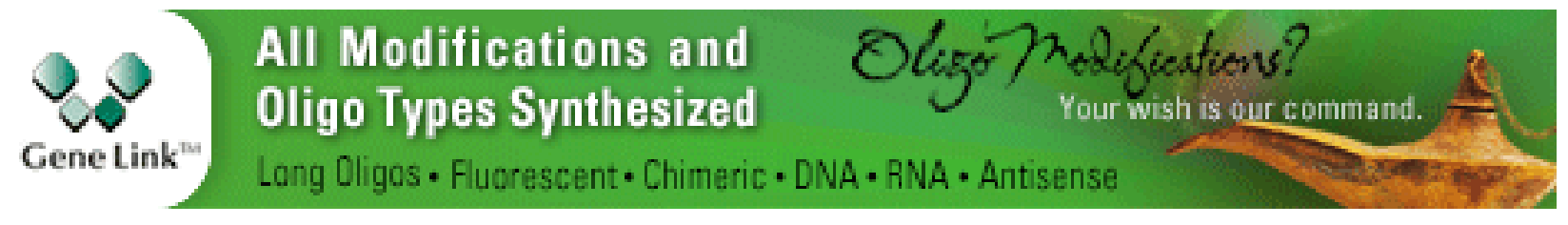

Copyright @ 2010 Cold Spring Harbor Laboratory Press; all rights reserved 